\title{
La muralla norte
}

\author{
Jose Luis Castillo Armenteros* \\ Juana Cano Carrillo*
}

Suele denominarse así al largo tramo que con dirección Sur-Norte baja desde los alcázares de la cima hasta el llamado carril de La LLana (Láms. n. ${ }^{\circ} \mid \mathrm{A}$ y |B), y que cierra el cerro y la ciudad por el Oeste. La construcción de la carretera de acceso al Parador de Turismo, que serpentea en su último tramo por este lado del cerro, afectó en varios puntos a la muralla y a alguna de las torres existentes, así como a la antigua puerta de entrada a los alcázares.

Este estudio identifica las torres dibujadas por Van den Wyngaerde, con las descritas por E. Chiquero y E. Moreno (1990), añadiendo la información arqueológica y estratigráfica obtenida por nosotros en esta zona en 1994.

Wyngaerde dibuja 16 ó 17 torres o torreones [alguna es dudosa] y tres puertas. De ellas, las dos primeras aparecen flanqueadas por torres, mientras que la tercera estaba protegida por una sola torre y la fuerte caída del terreno, o quizá el paso estaba dentro de la propia torre. Entre las dos primeras puertas dibuja 8 o 9 torres, y entre la segunda y la tercera otras 7 .

Sobre el terreno se han localizado 4 puertas. La I a (Lám. n. ${ }^{\circ}$, puerta) es la que protege, hoy como en época medieval, el acceso a los alcázares. A continuación se encuentra el pequeño Portillo del Carril (Lám. n. 3 3, portillo 1. $\left.{ }^{\circ}\right)$, que no dibuja Wyngaerde, en efecto, éste no puede identificarse con la $2^{a}$ puerta de aquél entre otras razones porque entre este portillo y la Ia puerta sólo se han localizado dos torres, y una de ellas prácticamente ya desaparecida. Por tanto la $2^{a}$ Puerta que dibuja debe tratarse de la que actualmente se denomina Puerta Nueva, aunque él reserva ese nombre para la tercera, que debe corresponder con la que existía en el carril de La Llana. Es muy posible que el cambio de denominación actual se deba a la desaparición de esa tercera puerta, cuyo nombre se ha "corrido" hacia la superior.

Por lo que se refiere a las torres, entre la Puerta de los alcázares y el Portillo del carril hay 3 torres, entre éste y la actual Puerta Nueva hay 9, y entre ella y La Llana otras 5, es decir un total de 17. Si tenemos en cuenta que alguna de ellas sólo ha podido detectarse a través del estudio arqueológico, resulta evidente la fiabilidad del dibujo de Wyngaerde. En nuestro estudio dicho dibujo ha servido para confirmar el número de torres. Para facilitar la localización de los diversos elementos, hemos subdivido la muralla en base a las puertas y portillos existentes en el mismo.

Es imposible fechar con seguridad la Puerta que hoy da acceso a la cima del cerro y a

* Departamento de Territorio y Patrimonio. Universidad de Jaén 
los alcázares Viejo y Nuevo, ya que esta puerta, al igual que el castillo y otras partes de la fortificación sufrió a partir de 1965 diversas intervenciones restauradoras. De las dos torres que la flanqueaban según Wyngaerde, solo queda una. Es de planta cuadrada (Lám. n. ${ }^{\circ} 4$, puerta principal), relativamente esbelta, realizada en mampostería irregular, y con sillarejo en las esquinas, características por las que se ha propuesto fecharlo en el siglo XIV.

El primer sector se extiende entre la Puerta y la carretera. Hay dos tramos. En el primero (A) hubo una torre (2) quizá omeya, que fue anulada en su mayor parte por los sucesivos refuerzos. A continuación hay un portillo que en la actualidad está cegado. En este sector se observan diferentes tipos de mampuestos, así como los cimientos de la torre, destruida casi en su totalidad. De la muralla original no queda ningún resto visible y sí de los diferentes revestimientos tanto internos como externos. El de más antigüedad es el construido en la cara interna, elaborado con mampostería ordinaria y sobre el que apoyará otro que vino a sustituir los restos que aún existían de las defensas islámicas por mampostería irregular. Más tarde este revestimiento será reparado (zona inferior) con mampostería mixta con doble hilada de ladrillo. El área próxima al postigo es de construcción más reciente (tapial de tierra sobre basamento de mampostería irregular escalonado), a excepción de los cimientos de la torre fabricados con mampostería irregular sobre el que se elevan tapiales de tierra revestidos de argamasa. (Lám.n. 5A y Lám.n. 5B).

En el tramo (B), situado a continuación del Portillo, quedan aun restos de la muralla de tapial de tierra, revestida luego de argamasa, muy deteriorada, y que ha sido doblada al interior con un paramento de mampostería irregular. Posteriormente en la zona externa, donde la muralla original había desaparecido, se construyó un muro de mampostería irregular con hiladas alternas de ladrillo, que incluso recrecerá el revestimiento interno anterior. Será en este momento cuando se construye el Postigo, que está cubierto con bóveda rebajada de ladrillo (cegado en la actualidad). Apoyado en los cimientos de la muralla se observan los res- tos de un revestimiento de mampostería que pudo doblar una torre (3) original de tapial destruida con la construcción de la carretera. (Lám. n. ${ }^{6}$, lienzo).

El segundo sector se ubica por debajo de la carretera. En el se han localizado unas 15 torres -una es dudosa- de muy diferentes características y dos puertas o portillos, a los que hay que añadir el Postigo que cerraría el acceso al Carril de la Llana en que terminaba el recorrido de este lienzo. Los tramos de muraIla ligados a las torres y puertas, presentan diversidad de características, reformas y estados de conservación. Describiremos a continuación las torres y los tramos de muralla que existen entre ellas.

Al otro lado de la carretera hay un transformador eléctrico. Por dabajo hay una estructura identificada como una torre (4)(Lam. n. ${ }^{\circ}$ 7) Tanto ésta como los lienzos que parten de ella están fabricados con igual material: tapial de tierra, dispuesto en tongadas, con revestimiento de argamasa. La torre es de dimensiones pequeñas y sus caras tienen proporciones desiguales (I'80×2'50×060). Frente a ella aparecen los cimientos del antemuro defensivo que protegía la muralla norte. Pero hay que advertir que más que una torre parece un sistema constructivo en el que se pretende quebrar las líneas rectas de los lienzos para conseguir una mayor solidez de la estructura defensiva, que se podía ver afectada en un momento dado por el gran desnivel que la base geológica presenta en esta zona del cerro. Por otro lado, con este sistema se evita la construcción de una torre.

- Lienzo de muralla que parte desde la torre (C) próxima al transformador eléctrico (Lám. n. ${ }^{\circ}$ ). Este tramo de muralla fue levantado en tapial de tierra con revestimiento de argamasa de una tonalidad rojiza. Posteriormente fue reparado con tapial de tierra en tongadas y revestido con argamasa de tonalidad amarilla. El deterioro del lienzo provocó la sucesiva reparación del mismo, en momentos históricos difíciles de precisar, con diversas mamposterías: En la parte superior se utiliza mampostería irregular enripiada con material cerámico sobre la 
que se elevará un tapial de tierra, hoy desaparecido. En la zona inferior tenemos mampostería irregular enripiada y unida en seco.'

Cuando se hace la primera reparación se construyó la torre de la que parte el lienzo, indicándonos que los dos tapiales tienen cronologías distintas (Lám. n. ${ }^{\circ 9}$ ). El primero es el originario, el emiral, con el que se construyen las primeras defensas islámicas, y el segundo corresponde a época almohade, cuando se reparan los tramos de muralla destruidos o deteriorados y se construye, además, el antemuro defensivo. Las mamposterías son de épocas diferentes: la superior tiene mucha similitud con la de la zona del Postigo del carril y la inferior posiblemente sea más moderna, aunque no podemos precisar cronologías exactas.

- Torre de planta cuadrada (5)(Lám. n. ${ }^{\circ}$ 0), fabricada en tapial en tongadas, con un revestimiento de argamasa amarilla. Posteriormente a la torre se le añadirá una camisa de mampostería irregular enripiada unida con mortero de cal, con la particularidad de tener las esquinas redondeadas. en la actualidad el paramento casi ha desaparecido. La cara interna se forra con un tapial de argamasa sobre basamento escalonado de mampostería irregular y el espacio entre ellos será rellenado.

Por asociación de elementos y observando la superposición de los dos tipos de fábrica en otros puntos, podemos señalar que esta torre de tapial podría sustituir a otra anterior, también de tapial de tierra, cuando en época almohade se renuevan las defensas. La mampostería pertenece a época cristiana, posiblemente a los siglos XIV-XV, cuando la aparición de la artillería hace que se refuerzen las torres con nuevos sistemas para una mayor resistencia (esquinas redondeadas). El revestimiento interno de tapial es más moderno, desconociendo su cronología concreta.

- Lienzo (D) original de tapial de tierra con revestimiento de argamasa rojiza, sobre cimiento escalonado de mampostería irregular enripiada con algún elemento cerámico y unida con mortero de cal y yeso. Posteriormente el lienzo fue restaurado con tapial de tierra ela- borado con tongadas y revestido con argamasa amarillenta. En el tramo inferior, el tapial original es doblado de mampostería mixta, la cual romperá la torre anexa al lienzo. La unión de estos mampuestos con el tapial se resuelve mediante arista de sillarejo. A intramuros se construye una hoja de tapial de tierra sobre basamento escalonado de mampostería irregular, el cual se levantó una vez destruida la antigua muralla y su posterior restauración (Lám. n. ${ }^{\circ}$ I, extramuros y Lám. n. ${ }^{\circ}$ 2, intramuros).

La superposición de estructuras está bien definida en esta área en la que se aprecia perfectamente las distintas modificaciones que afectan al lienzo antiguo y finalmente la eliminación de éste, que dará paso a una hoja nueva de tapial que se levantará a intramuros, rellenándose el espacio entre los dos elementos.

- Torre original de tapial de tierra (6)(Lám. n. ${ }^{\circ}$ 3), que posteriormente será revestida con argamasa amarillenta, configurando su cimiento de forma escalonada. La estructura se vio muy afectada al edificarse en parte de su espacio un revestimiento de mampostería mixta cuyo objetivo era reforzar los lienzos de este área. A intramuros, de la muralla original tan sólo queda el cimiento de mampuestos irregulares, siendo sustituida por un lienzo que cabalga sobre el anterior, fabricado en mampostería irregular y cuya cronología es anterior a los revestimientos de la zona extramuros.

- Lienzo de muralla (E) entre los restos de la torre con basamento escalonado y una torre de tapial (Lám. n. ${ }^{\circ} 4$ ). A extramuros, actualmente el lienzo original emiral ha desaparecido, tan sólo quedan vestigios de los cimientos de mampostería irregular. El lienzo fue reelevado en la parte inferior con tapial de tierra con revestimiento de argamasa, ya en el periodo almohade. También se han podido recuperar restos del antemuro fabricado en tapial de tierra con revestimiento de argamasa.

- Torre de mampostería (7) irregular ciclópea de época ibérica tardía (Lám. n. ${ }^{\circ}$ 5). Restaurada con sillares más pequeños y unidos con mortero de cal, sobre el que se levanta una torre de tapial de tierra con revestimiento de 
argamasa (torre original emiral), y que posteriormente fue reelevada con tapial de tierra en tongadas y revestimiento de argamasa amarilla (modificación almohade).

En este tramo de muralla (F), los únicos restos que quedan del lienzo original son los cimientos y la primera línea de cajones, en tapial de tierra con revestimiento de argamasa rojiza, con gran cantidad de grava. Una hoja de tapial de argamasa de color amarillo dobla y recrece al anterior, la unión entre ambas hojas se garantizaba a través de rollizos de $16 \mathrm{cms}$. de diámetro dispuesto en retículas de $2 \times 2$ '5 m. a modo de presillas. Se conserva el adarve superior con un escalonamiento de $50 \mathrm{cms}$. cada $3 \mathrm{~m}$. Toda la reforma del lienzo sería del periodo almohade. (Lám. n. $\left.{ }^{\circ} \mid 6\right)$.

- Torre (8)(Lám. n. I7A) fabricada en tapial de argamasa rojiza con macizado interior de tierra. Reparada con mampostería regular unida con mortero de cal y yeso en una de sus esquinas, y finalmente revestida con un forro de tapial de tierra con abundante mampostería y basamento escalonado. La reparación, con mampostería irregular unida con yeso y cal, se hace cuando todavía se utiliza el sistema defensivo del antemuro e incluso puede ser anterior a la creación de este, utilizándose de esta forma, en dos momentos diferentes.

La torre original seguramente se edificó en el periodo emiral. El forro de mampostería irregular unido con mortero de cal y yeso es anterior a la época almohade y posiblemente posterior al califato. El forro de tapial con abundante piedra se levantaría en época cristiana cuando ya estaba inutilizado el sistema defensivo del antemuro. (Lám. n. ${ }^{\circ}$ ।7B).

Del lienzo original de tapial de tierra (G), tan sólo quedan sus cimientos. El lienzo fue doblado por: en la parte superior, en un principio por una hoja de tapial de argamasa amarilla (época almohade) que fue destruido y sobre el cual se elevó un lienzo de mampostería irregular unida con mortero de cal y abundante material cerámico, observándose una arista de sillarejo que soluciona el quiebro con el extre- mo inferior. Coronando este muro quedan restos del paramento del adarve. En la parte inferior, sobre el cimiento de mampostería ordinaria unida en seco se levanta un tapial de tierra. En esta zona de la muralla quedan restos de una puerta, actualmente cegada. (Lám. n. ${ }^{\circ}$ 9).

- Torre (9)(Lám. n. ${ }^{19}$ ) de tapial de tierra, forrada y recrecida con mampostería irregular con argamasa amarilla. En fases posteriores la torre será reparada utilizando mortero de cal y yeso. A intramuros se conservan los restos de la muralla construida en tapial de tierra.

En esta torre es posible datar algunas de las fases de construcción, la base de mampostería ciclópea corresponde a una estructura romanoaugústea. De época emiral es el tapial de tierra de la torre y del lienzo intramuros. La mampostería revestida de argamasa es de una cronología anterior a la época almohade. Por el contrario la reparación con yeso y cal se realizó posteriormente a la fase almohade, cuando se recrece el lienzo anteriormente descrito.

- El lienzo $(H)$ es, intramuros, el original de la muralla de tapial de tierra con revestimiento de argamasa de color rojizo y que aprovecha los restos existentes de las defensas del periodo iberorromano (Lám. n. ${ }^{\circ 20}$ ). La hoja original es doblada por un forro de tapial de tierra con revestimiento de argamasa de color amarillo, el cual se apoya sobre los restos del recinto ibérico con mampostería irregular ciclópea. Sobre este lienzo se reeleva un forro de mampostería irregular revestida con mortero de cal y yeso. En este tramo de la muralla también se conservan restos del antemuro. El tapial original corresponde a época emiral. El forro de tapial de tierra con revestimiento de argamasa amarilla fue levantado en el periodo almohade, a la vez que se construía el antemuro, fabricado con el mismo material. Sin embargo, es difícil adscribir a una cronología concreta la realización del forro de mampostería unido con mortero de cal y yeso.

- Torre cuadrangular de perfil ataluzado (I0) (Lám. n. ${ }^{\circ} \mathrm{I}$ ) de origen iberorromano construida en mampostería irregular ciclópea unida 
en seco y con basamento escalonado. Sirve de cimiento a una torre de tapial de argamasa con muchos mampuestos. La cara de intramuros reeleva o se monta sobre la antigua muralla de tapial de tierra, por lo que esta torre se edificó posteriormente a la construcción de la muraIla, aunque en un mismo momento histórico. Desconocemos si sustituye o forra a otra torre anterior. Paralela a ella quedan restos del antemuro de tapial de tierra con revestimiento de argamasa amarilla construido en época almohade. Es posible que la torre pueda tener un origen califal.

- Lienzo de tapial (Lám. n. ${ }^{222}$ ) de tierra forrado por las dos caras (I): En la cara externa se dobló el lienzo original de tapial de tierra con otro tapial revestido de argamasa amarilla. Posteriormente y tras la destrucción de éste, se fabrica sobre él un forro de mampostería irregular alternada con verdugadas dobles de ladrillo tomadas y revestidas con mortero de cal y yeso. En fases más tardías el elemento se recrece y dobla por la cara interna con mampostería irregular enripiada, aunque ha perdido casi todo su acabado externo. La cara interna sufre una reparación o realce en su parte inferior con abundante mampostería y mortero de cal y yeso. El forro de tapial de tierra con argamasa amarilla se levantó en época almohade, mientras que las reparaciones de mampostería corresponden a fases cristianas, aunque es imposible adelantar cronologías absolutas.

- Torre de tapial de argamasa (Lám. n. ${ }^{\circ 23),}$ con relleno interior de tierra (I I). Por la cara interna se monta sobre el lienzo de la muralla original de tapial de tierra. Desconocemos si forra o sustituye a otra torre anterior. Tiene el cimiento escalonado y está algo ataludada. Frente a ella aún se conservan restos del antemuro.La torre podría tener un origen califal, puesto que se apoya sobre la muralla original, aunque también pudo ser construida a la vez que la muralla, adosándose a ella.

- Lienzo de muralla (I) entre dos de las torres de planta completa que se conservan (Lám. n. $\left.{ }^{2} 24\right)$. El lienzo de tapial original fue doblado en la cara externa por otra hoja de tapial de tierra revestido de una argamasa rojiza, levan- tado por el sistema de tablillas. Este forro se hizo después de la construcción de la torre anterior, pero seguramente en la misma fase cronológica. Se puede adscribir el forro a la época califal mientras que el lienzo sería el original de la muralla.

- Torre original de tapial de tierra (Lám. n. $25 \mathrm{~A}$ y Lám. n. $25 B$ ) con revestimiento de argamasa roja y lienzo fabricado en el mismo material. A extramuros, la torre en un primer momento fue forrada con mampostería irregular unida y revestida de mortero de cal y yeso. Posteriormente se la encamisó con un forro de tapial con mucha piedra, el cual destruye el antemuro, que fue reparado en algunos tramos con mampostería irregular unida con mortero de cal. Es difícil adscribir cronológicamente las distintas reparaciones. Lo que sí es seguro es que la camisa de tapial es de época cristiana, puesto que destruye el antemuro.

- Lienzo original (Lám. n. $\left.{ }^{2} 26\right)$ construido en tapial de tierra con revestimiento de argamasa (K), del que tan sólo se conserva el tramo que se adosa a la torre anteriormente descrita, hasta pasar el postigo de Puerta Nueva. El tramo inferior fue levantado de nueva planta, sobre un cimiento de mampostería irregular, con tapial de tierra en el que se ven las agujas cubiertas por piedra y dispuestas en retícula y con revestimiento de argamasa amarilla. A intramuros el lienzo se dobla y recrece con mampostería irregular unida con mortero de cal. El paramento irregular se ha conservado sólo en la zona inferior. En este tramo existe un postigo conocido como Puerta Nueva recientemente restaurado, con bóveda carpanel construida en ladrillo. El cimiento y tapial son de las últimas fases constructivas de las murallas, en el periodo cristiano. (Lám. n. ${ }^{\circ 26}$ y Lám. n. ${ }^{\circ 27) .}$

- Tramo de la muralla $(L)$ donde se produce el quiebro del trazado de la misma. Encontramos una gran complejidad arquitectónica (Lám. n. ${ }^{\circ} 28$ y Lám. n. ${ }^{\circ 29): ~}$

- Tapial original del que tan sólo quedan restos en la esquina de una torre (13) y una parte del lienzo perdido entre los diferentes revestimientos. 
- Posteriormente, por la ruina de los lienzos originales, estos se forran con tapiales de tierra con gran cantidad de cal en su composición, que le dará mayor resistencia.

- La cara externa será recrecida y doblada por la mampostería irregular enripiada con mortero de cal.

- También la cara interna será forrada con mampostería y mortero de cal. Aún se ven los restos de una escalera que comunica con el adarve adosado al lienzo de muralla.

- Una hoja de tapial de muy reciente factura.

La torre y los restos de tapial son emirales. Mientras que los forros de tapial son de una época bastante tardía, posiblemente cristiana, en un momento en el que ya no se utilizaba el antemuro. También cristiana, pero de una fase posterior, serán las mamposterías, mientras que las últimas reformas de tapial son de este siglo. A extramuros el terreno presenta una planicie totalmente artificial, que se dirige hacia este tramo de muralla, lo cual nos indica que es muy posible que hubiese una puerta en esta zona de la muralla. También se amplió la torre, quedan restos de pavimentos de cal y piedras, etc. Estas reformas se hicieron durante el califato."

Torre original de tapial de tierra ( 14)(Lám. n. ${ }^{\circ 30 A ~ y ~ L a ́ m . ~ n . ~}{ }^{\circ 30 B}$ ) que posteriormente fue doblada y replanteada en forma poligonal con tapial de argamasa. El antemuro almohade también rodea la torre adecuándose a su forma. Finalmente la torre será destruida, y de nuevo forrada, siguiendo un trazado recto con respecto al lienzo de muralla, con mampostería irregular enripiada, que ha sido restaurada recientemente.

A extramuros el lienzo original $(M)$ se apoya sobre un cimiento escalonado de mampostería ciclópea (Lám. n. 31 I). Sobre ella se alza otro paramento de mampostería irregular con argamasa en el que se observan las huellas de los maderos utilizados en el encofrado. El muro se recrece con tapial de tierra. Al exterior tenemos recrecidos de tapial de argamasa o de tierra con mucha cal en su composición sobre basamento escalonado y recrecido de mampostería irregular enripiada.
La mampostería ciclópea puede pertenecer a la ocupación iberorromana de la zona, o ser materiales reutilizados de esta época. El tapial original es emiral mientas que el forro del tapial de argamasa es posiblemente califal. Los recrecidos en mampostería son muy posteriores, de época cristiana.

Torre original de tapial de tierra (15)(Lám. n. ${ }^{\circ 32 A}$ y Lám. n. ${ }^{\circ 32 B}$, detalle) revestida de argamasa rojiza con cimiento escalonado, que fue posteriormente forrada con mampostería irregular y mortero de cal. La torre tiene las esquinas redondeadas. Finalmente se recrece a intramuros con mampostería, que ha sido recientemente restaurada." "El forro que se le hace a la torre original es de época cristiana. El recrecido es difícil de datar.

A intramuros el lienzo original de tapial de tierra $(\mathrm{N})$ ha desaparecido y tan sólo queda el cimiento (Lám. n. ${ }^{\circ 33) . ~ A ~ e x t r a m u r o s, ~ t e n e m o s ~}$ un forro de tapial de argamasa con bastantes mampuestos, donde se aprecian las huellas de las tablillas empleadas en su ejecución y de los rollizos usados para unirlo al lienzo original. El forro del que hablamos es califal.

Torre original de tapial ( 16)(Lám. n.934) de tierra reestructurada y forrada con mampostería irregular y sillarejos en las esquinas, haciendo posible la habitabilidad de la torre en la última planta donde se observa una saetera. Delante de ella se han encontrado los restos del antemuro y de un antiguo forro de tapial amarillo que forraba la torre original, aunque ambos están encubiertos por una camisa de mampostería. A intramuros el lienzo original se ha forrado con mampostería irregular recientemente. El forro de tapial amarillo y el antemuro son almohades mientras que las camisas de mampostería son cristianas.

Lienzo de muralla $(\tilde{N})$ de tapial de argamasa levantado de nueva planta, con las huellas de las tablillas del encofrado o dos forros ya unidos (Lám. n. 35). Recrecido el lienzo con mampostería irregular alternada con dobles hiladas de ladrillos dispuestos a soga y tizón. La parte superior del lienzo ha sido restaurada recientemente con argamasa de color rojizo. El 
lienzo se levantó en época califal sustituyendo al antiguo tapial emiral totalmente destruido.

Torre (17) presumiblemente original (Lám. n. ${ }^{36}$ A y Lám. n. 36B), construida en tapial de tierra, con forma pentagonal, para salvar y defender el quiebro que de nuevo se produce en la muralla. Posteriormente será doblada con otro tapial de argamasa con mucha piedra que conserva perfectamente el sistema de tablillas con el que se levantó. Más tarde la torre se vuelve a forrar de nuevo con tapial de tierra revestido con argamasa amarilla, y todo ello es protegido por el antemuro que la rodea. La torre y el lienzo a intramuros son emirales

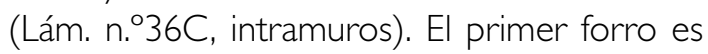
califal, mientras que el segundo y el antemuro son almohades.

En este punto debía localizarse el Postigo de la Llana (Lám. n. ${ }^{\circ 37), ~ d e l ~ q u e ~ s o ́ l o ~ h a ~ q u e-~}$ dado el nombre en el carril que pasa por este punto, y restos de la cimentación del lienzo que partía hacia la ciudad, realizado con mampostería irregular enripiada.

\section{Del Postigo de la Llana a la Puerta de Martos}

Wyngaerde dibuja 5 torres entre el Portón de La Llana y la Puerta de Martos a las que hay que añadir las 2 que dibuja protegiendo la propia puerta. En el tramo entre el Postigo de La Llana y la Puerta de Martos se han situado las torres Albarrana y del Comendador (Rodríguez Molina 1985) de las que $M^{a}$ S. Lázaro (1988:45) indica:

"Son torres de envergadura y destacables en el lienzo general de la muralla según se desprende de su elección para situar los diferentes turnos en las rondas. Poco o nada sabemos sobre la configuración de las mismas salvo que la torre Albarrana como su mismo nombre indica, se adelantaría sobre el plano general de la cerca quedando unida al adarve por medio de un arco y cuya misión era defender la muralla del atacante. [...] Pudiera plantearse la duda de si estas dos últimas torres pertenecían en realidad a la alcazaba o castillo. En los Acuerdos Capitulares jamás se menciona asunto ninguno referente $a$ éste a no ser los relacionados con la dotación de aceite para la lámpara de la capilla por lo que pensamos que, puesto que el castillo tenía guarnición y alcaldía propias, la Ciudad no establecía turnos de guardia en el. Por otra parte hemos tenido ocasión de manejar una escritura para la realización de obras y reparos en los castillos nuevos o castillo de Santa Catalina, en 1535, en la cual, si bien aparecen otras denominaciones, no aparecen las que antes mencionábamos. Por lo que cabe señalar la independencia de estas torres de las del castillo y su vinculación con la cerca general de la ciudad."

Según el dibujo de Wyngaerde, parece muy posible que la torre situada inmediatamente a continuación del Postigo de La Llana fuera una torre albarrana, si interpretamos el extraño trazo que presenta como el muro que uniría la torre con la muralla. El análisis de la zona realizado por E. Chiquero y E. Moreno (1990) registra en la zona cuatro torres, ninguna de ellas albarrana, que sería precisamente la que faltaría, quizá porque su alejamiento de la muralla la hizo menos resistente al tiempo:

"Torre original de tapial de tierra revestido de argamasa (I8). Posteriormente forrada con mampostería regular. Se restauró en 1980. Es conocida como 'Torre de Vedrines'. En su cara inferior muestra restos de su primitiva hoja levantada sobre basamento escalonado. De planta cuadrangular, presenta un chaflán interior a media altura, cota de acceso a una sala cubierta con bóveda hemiesférica de ladrillo apoyada sobre pechinas irregulares. Dispone además de una escalera interior embebida en los muros de la torre que conectaba los adarves que concurren en este elemento."

"Lienzo con adarve escalonado constituido por dos hojas: -Hoja exterior: tapial de tierra revestido con argamasa. Existente aún en la zona inferior. Ha sido sustituido por: $1^{\circ}$ en la zona superior: mampostería irregular, enrripiada y tomada con mortero de cal, $2^{\circ}$ en la zona intermedia: mampostería regular tomada con mortero de cemento incorporada en la restauración de 1980. -Hoja interior: forro de mampostería con paramento regular que dobla y recrece a la primitiva hoja de tapial. 
"Torre de planta rectangular sobre basamento escalonado que en su cara inferior presenta aún restos del original tapial de tierra revestido de argamasa. a intramuros se observa un posterior trasdosado ejecutado con mampostería regular. Al igual que otros elementos en 1980 fue restaurado por el arquitecto D. José $M^{a}$ Pardo Crespo. Esta intervención recompuso su volumen incorporando paramentos de mampostería regular aglomerada con mortero de cemento."

"Lienzo de tapial de tierra parcialmente desaparecido y revestido por ambas caras con argamasa. Su adarve escalonado, con parapeto incluido, presenta recrecidos puntuales de mampostería con paramento regular."

"Torre de planta rectangular que en su cara inferior presenta aún restos del original tapial de tierra revestido de argamasa. Al exterior muestra actualmente un paramento de mampostería regular con sillarejos en las esquinas. Al interior, sobre el tapial, se observa un recrecido escalonado de mampostería que conforma el adarve."

"Lienzo de tapial de tierra revestido de argamasa. Sobre su escalonado adarve se observa un recrecido de mampostería con paramentos regulares. A intramuros, en el extremo inferior y doblando el tapial se sitúan los restos de una escalera de acceso, con paramento regular de mampostería, que alcanza la torre adyacente."

"Torre de tapial de tierra incorporada en el tejido urbano de Jaén. Fue forrada y recrecida mediante una fábrica de mampostería y mortero de cal. Hoy día junto a los escasos restos de su paramento regular, únicamente se conserva un deforme hueco de acceso a una estancia cubierta."

Este tramo sería uno de los más afectados por las actuaciones defensivas del Condestable Miguel Lucas de Iranzo contra el prior de la Orden de S. Juan y los ocupantes del Alcázar Viejo en I467 (Relaciones... 200 I, p. 275):

"[...] el dicho señor condestable mandó derrocar e desbuçar todo el andamio del adarve que viene un poco abaxo del postigo en par de la Llana, de parte de la çibdad; por manera que persona ninguna de los dichos alcáçeres pudie- se andar po él, nin desçender a tomar torre alguna contra la dicha çibdad.

"Y mando tapiar las dos torres primeras que estavan mas çercanas al dicho adarve que su merçed mandó derrocar. E mandó çerrar todas las almenas, e techar las torres con tapiales e muy gruesas vigas, por las piedras e tiros de pólvora que de arriba tiravan.

"Y ençima de los dichos tapiales que en las dichas torres estavan, mandó poner unos mandeletes, porque más segura estoviese la gente debaxo dellos. Y en la segunda destas torres que así estavan tapiadas, mandó poner una media lombarda, con la cual tiravan a una ventana de una torre de las principales del alcaçar Nuevo. Las quales dichas torres estavan guarneçidas de muchos vallesteros y espingarderos, de noche y de dia.

\section{El Antemuro del Condestable}

Además de esas actuaciones sobre la antigua muralla, prosiguió con la construcción del nuevo recinto:

"E desde el hormazo bien alto que está en una viña de los dichos alcáçares fasta el camino que viene de la dicha çibdad a la sierra, mandó fazer una çerca de tapias, fasta la puerta de Martos, e bardallas muy bien; por manera que gente nin persona alguna, por una parte nin por otra, non pudiese entrar nin salir a los dichos alcáçares." (Relaciones... 200 I: 275).

\section{BIBLIOGRAFÍA}

Castillo, JL.; Cano, J. (1994): Diagnosis arqueológica de la Muralla Norte de Jaén. (Inédito).

Chiquero, E.; Moreno, E (1990): Ficha técnica del conjunto defensivo de la ciudad de Jaén. (Inédito).

Ciudades del Siglo de Oro. Las vistas españolas de Anton Van den Wyngaerde. (Ed. Richard L. Kagan) Barcelona 1986.

Lázaro Damas, Mª S. (1988): Desarrollo histórico del casco urbano de Jaén hasta 1600. Jaén.

Relación de los hechos del muy magnífico e mas virtuoso señor, el señor Don Miguel Lucas muy digno Condestable de Castilla. Ed. Juan Cuevas, Juan del Arco y José del Arco. Jaén 2001 


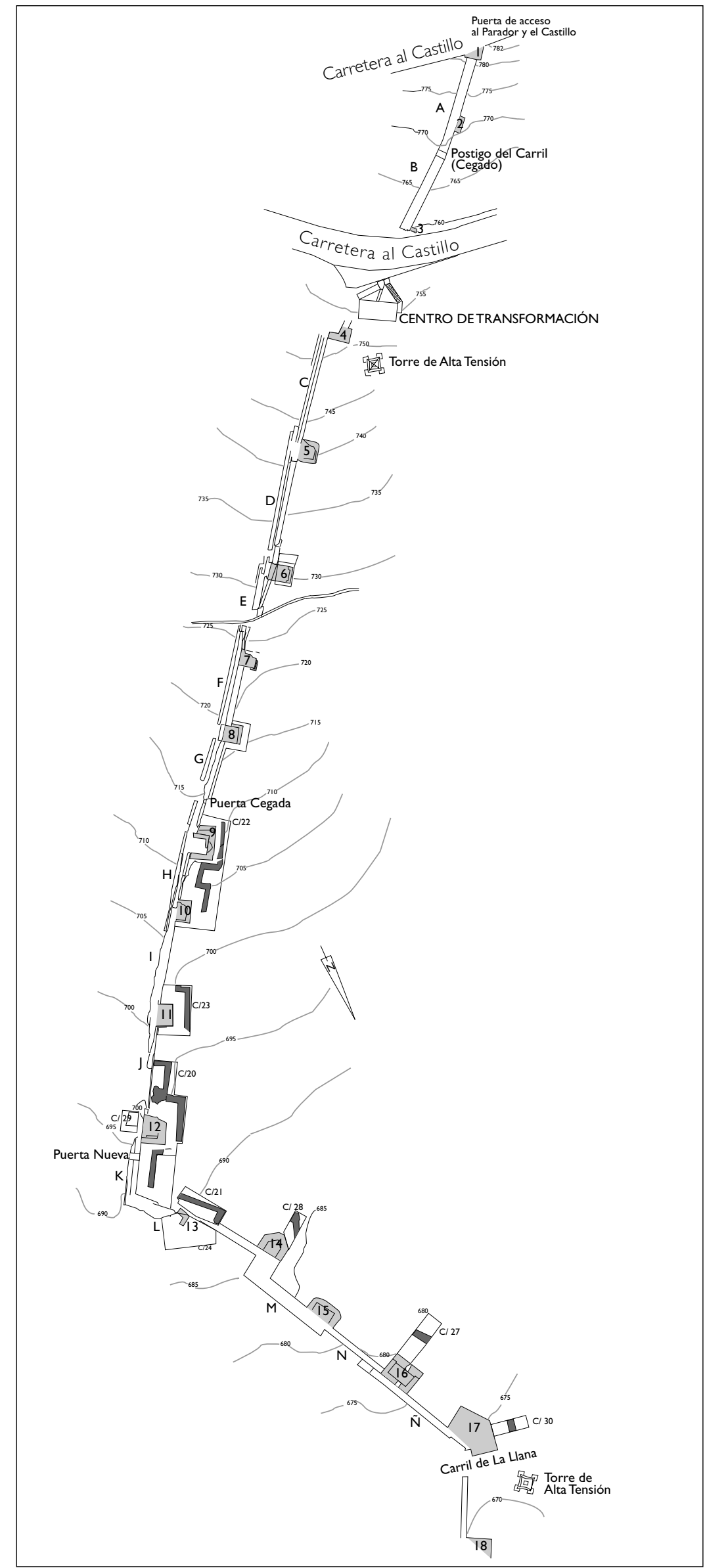

Figura I. Plano general de la muralla Norte 




Lámina IA. Vista general Muralla Norte y Alcázares

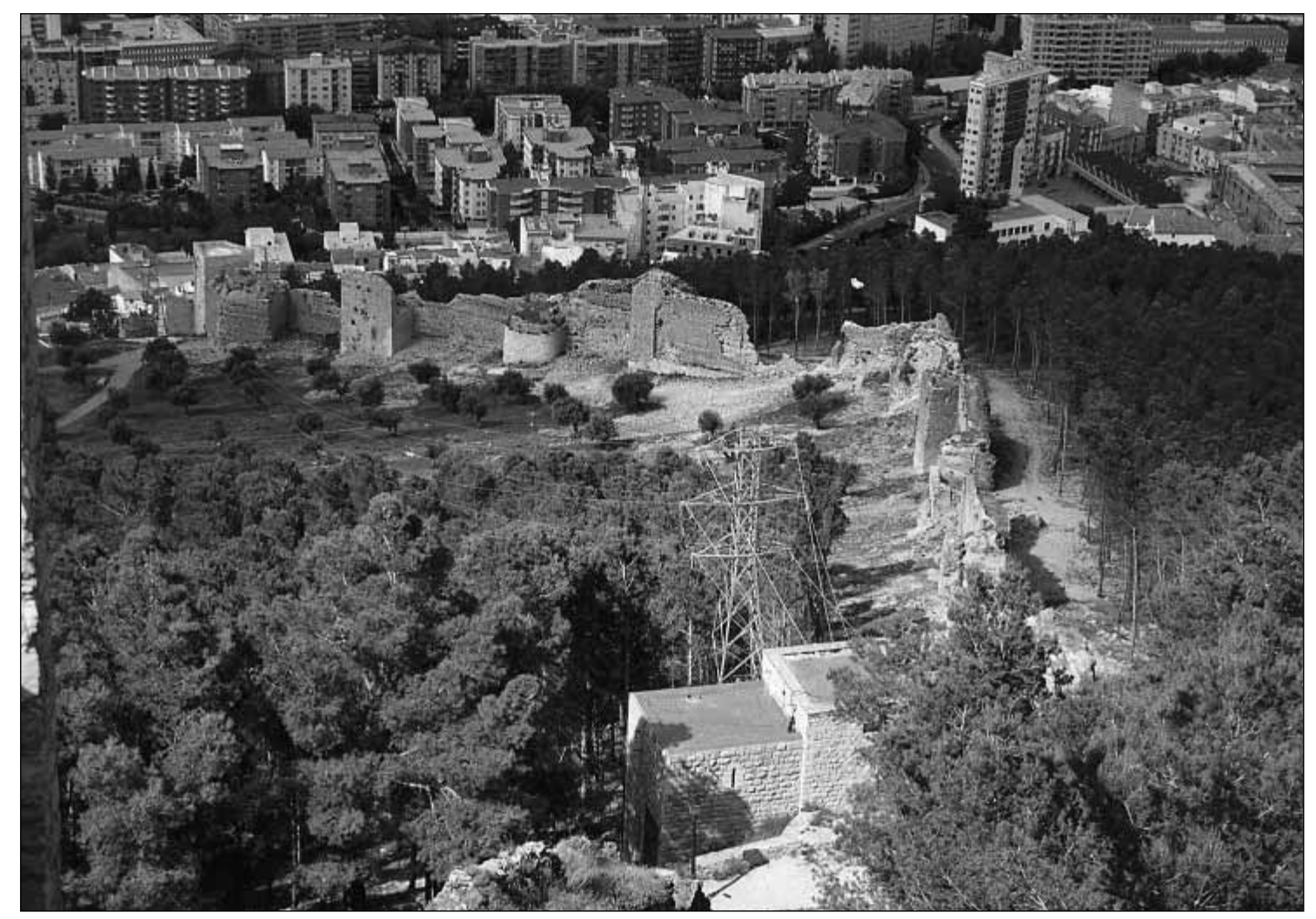

Lámina IB. Trazado de la Muralla Norte 


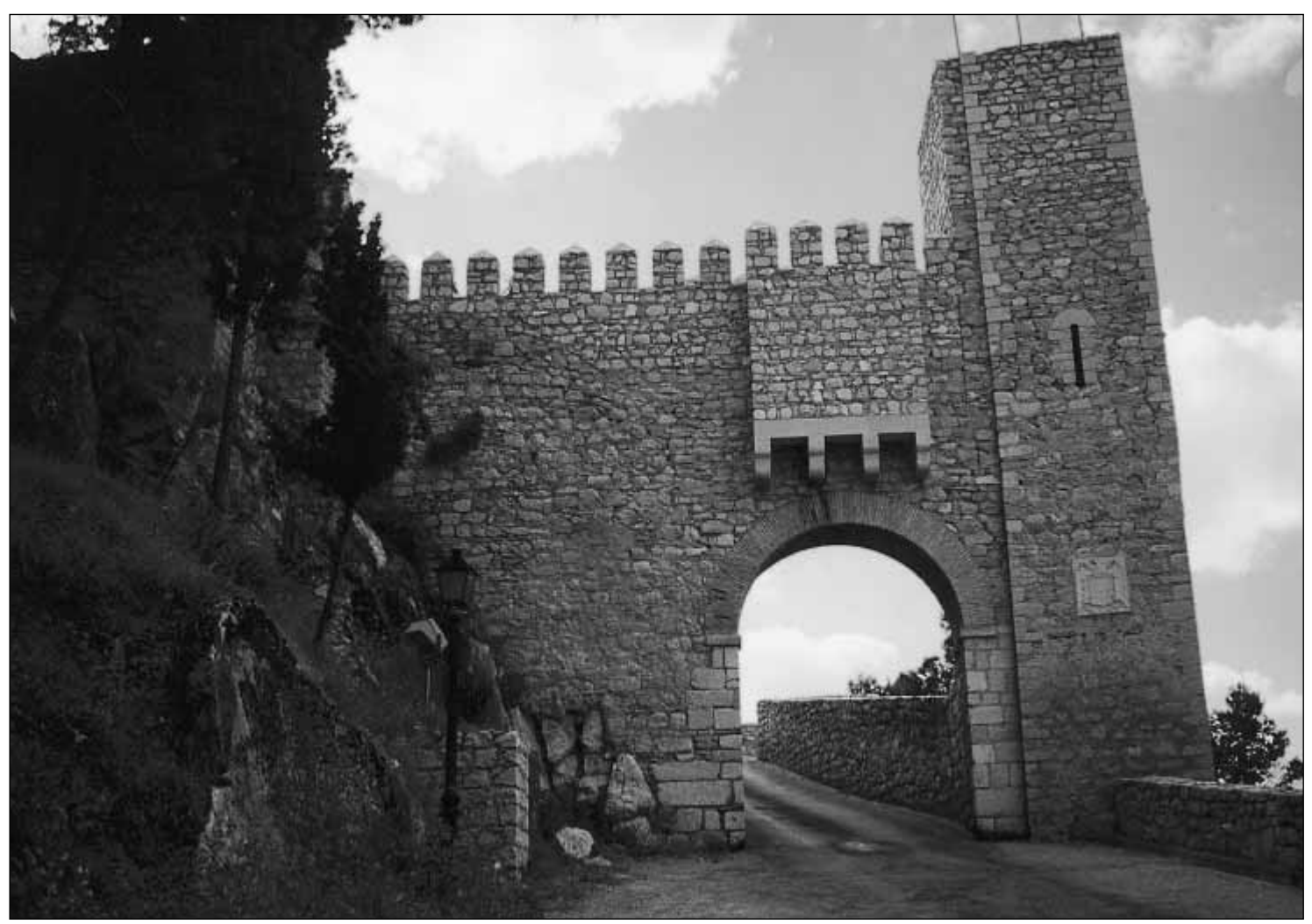

Lámina 2. Puerta de acceso a los Alcázares

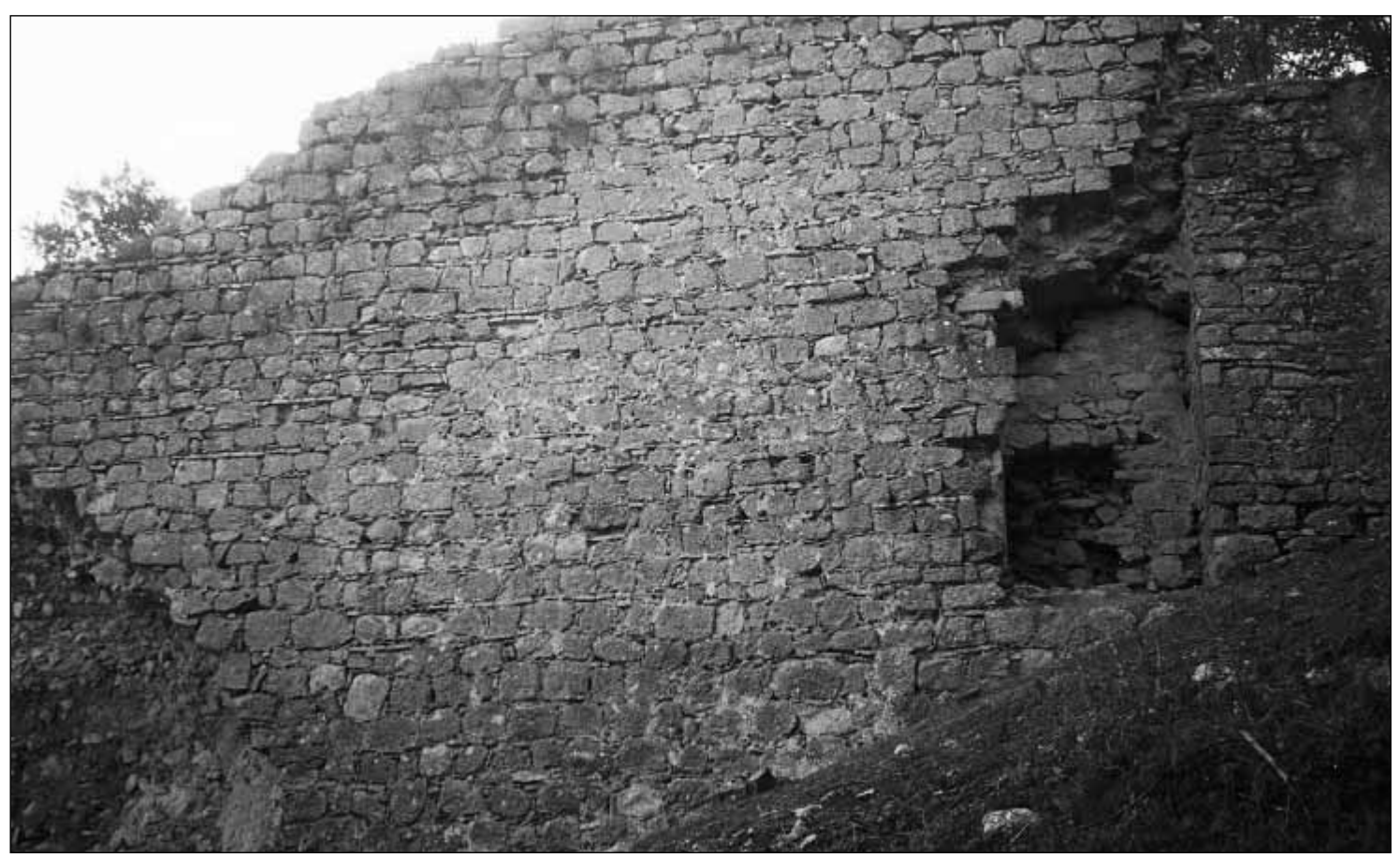

Lámina 3. Portillo del Caril 

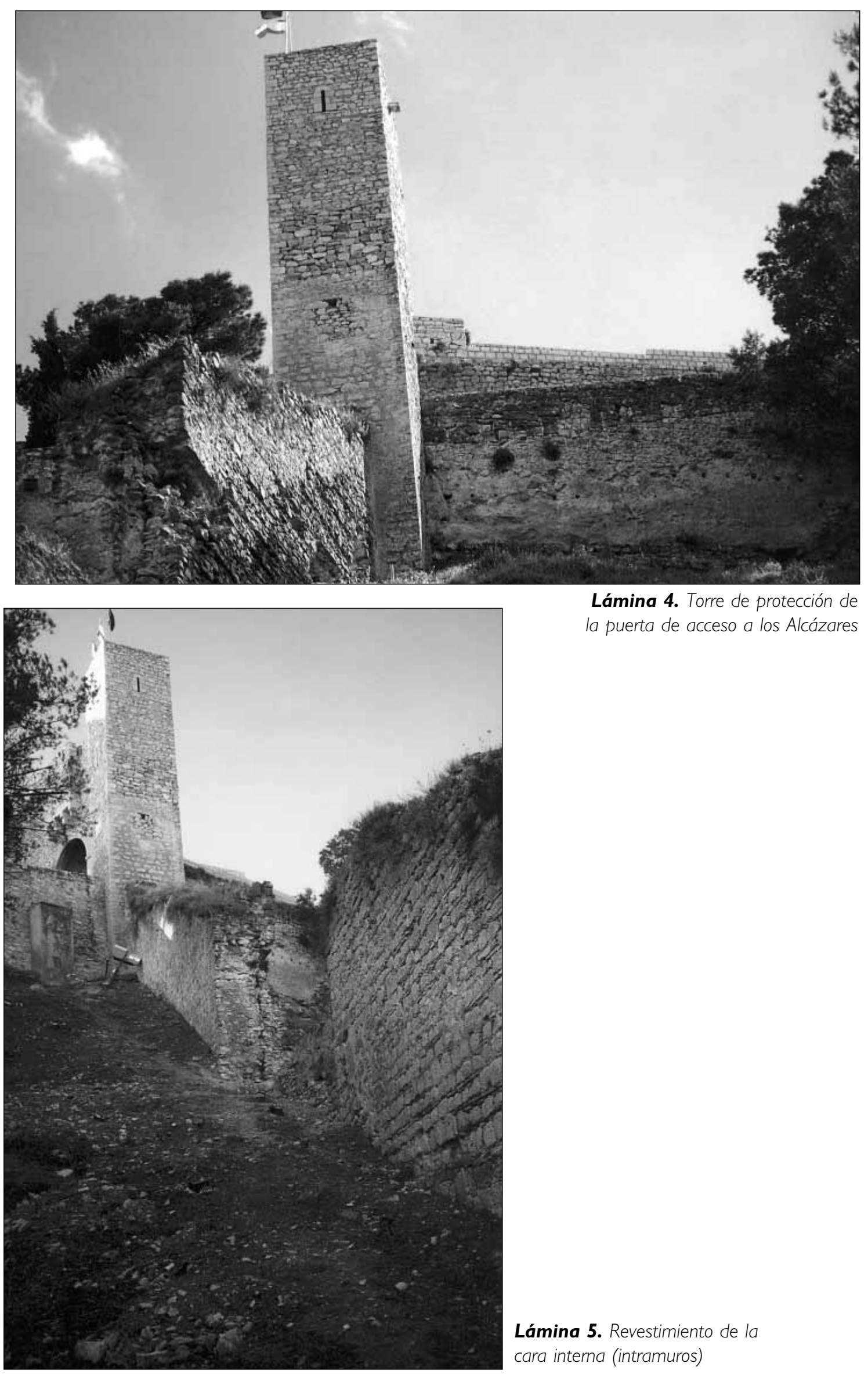

Lámina 4. Torre de protección de la puerta de acceso a los Alcázares

Lámina 5. Revestimiento de la cara interna (intramuros) 



Lámina 5B. Revestimiento de la cara externa (extramuros)

Lámina 6. Reparaciones

de la muralla original 




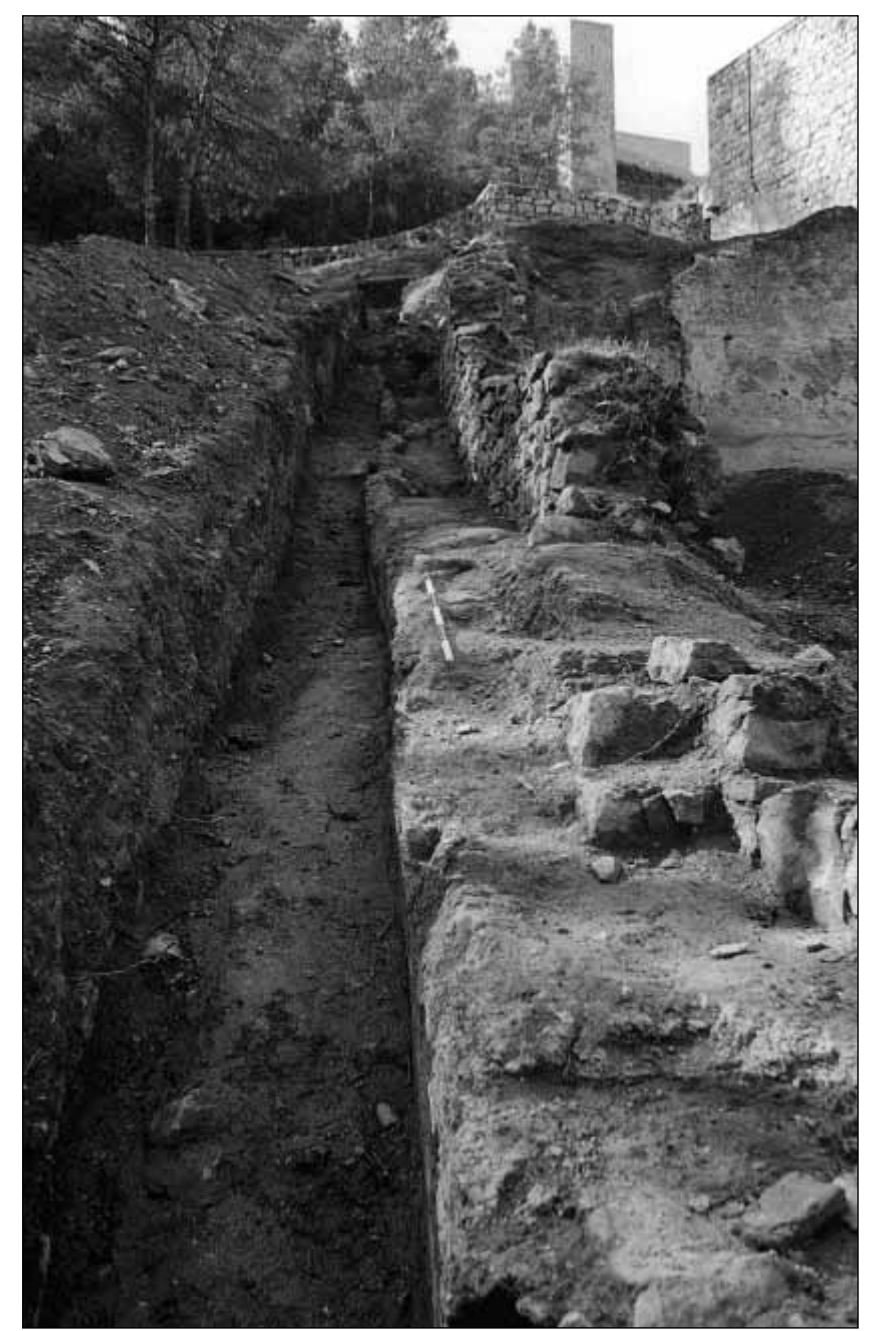

Lámina 7. Torre de tapial de tierra y revestimiento de argamasa o sistema de quiebro de la muralla

Lámina 8. Restos de la muralla

original y sucesivas remodelaciones 

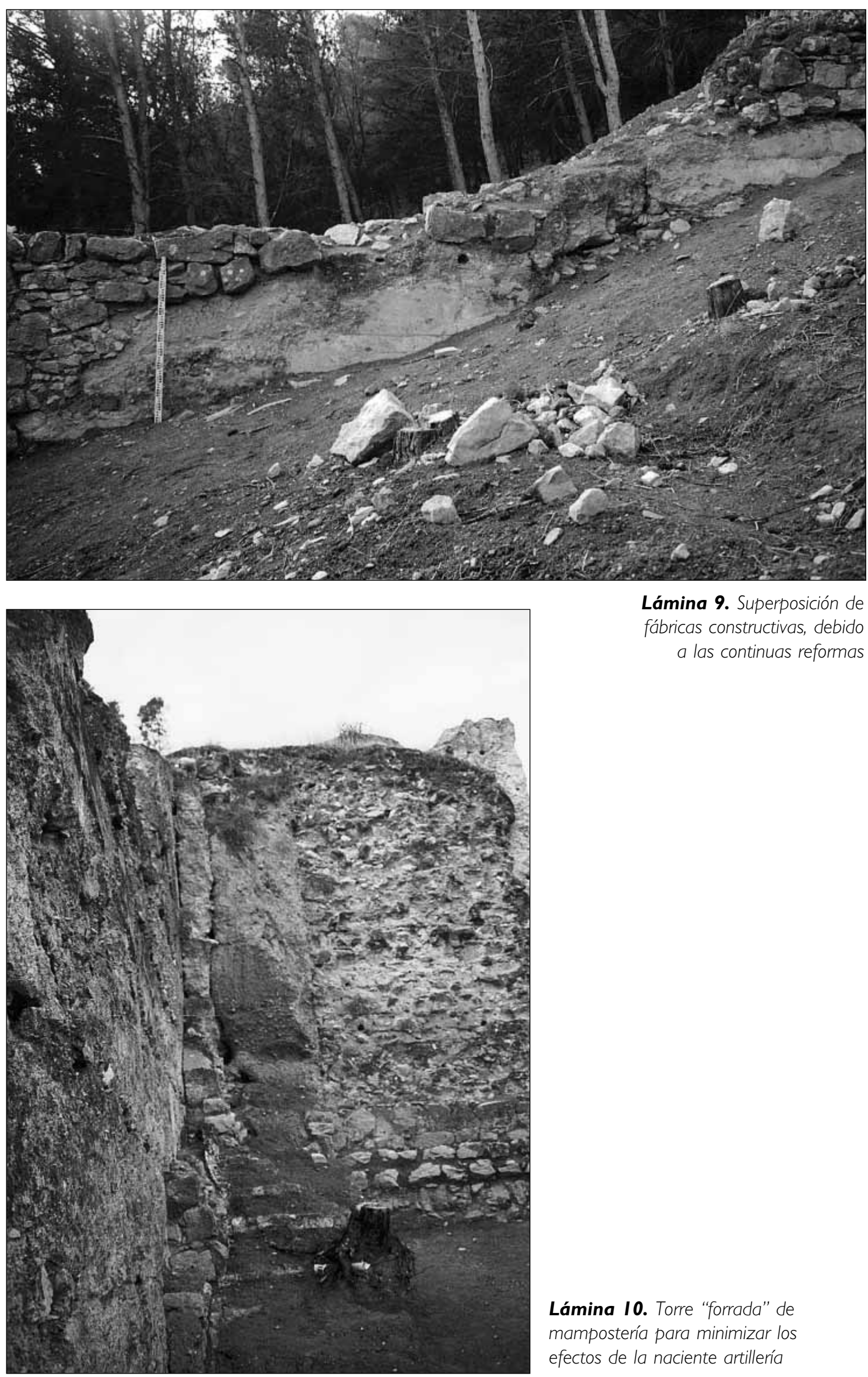

Lámina 9. Superposición de fábricas constructivas, debido a las continuas reformas

Lámina I0. Torre "forrada" de mampostería para minimizar los efectos de la naciente artillería 


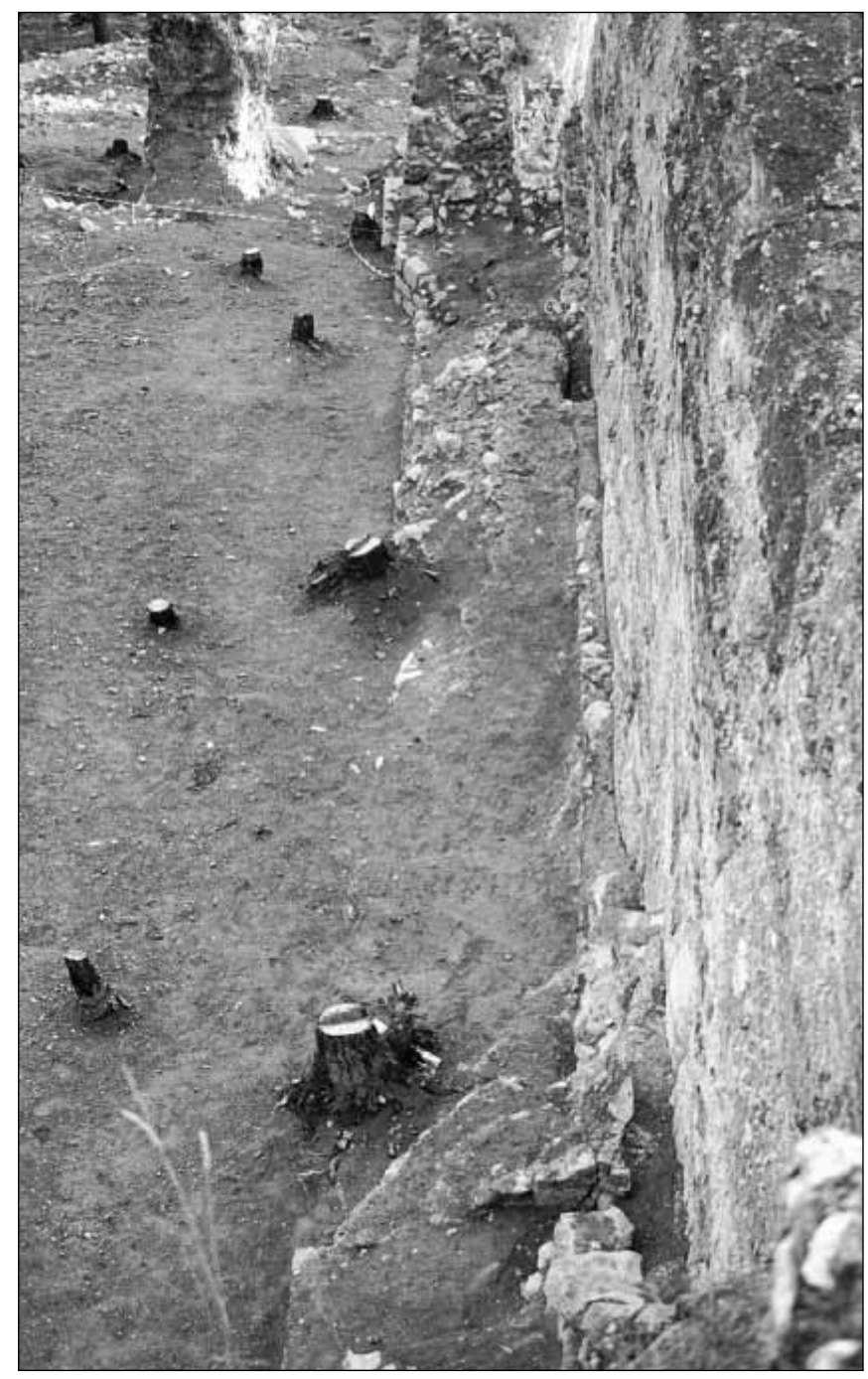

Lámina II. Reparaciones y refuerzos

de diferentes periodos históricos

Lámina I2. Paramento de tapial

que refuerza la cara de intramuros

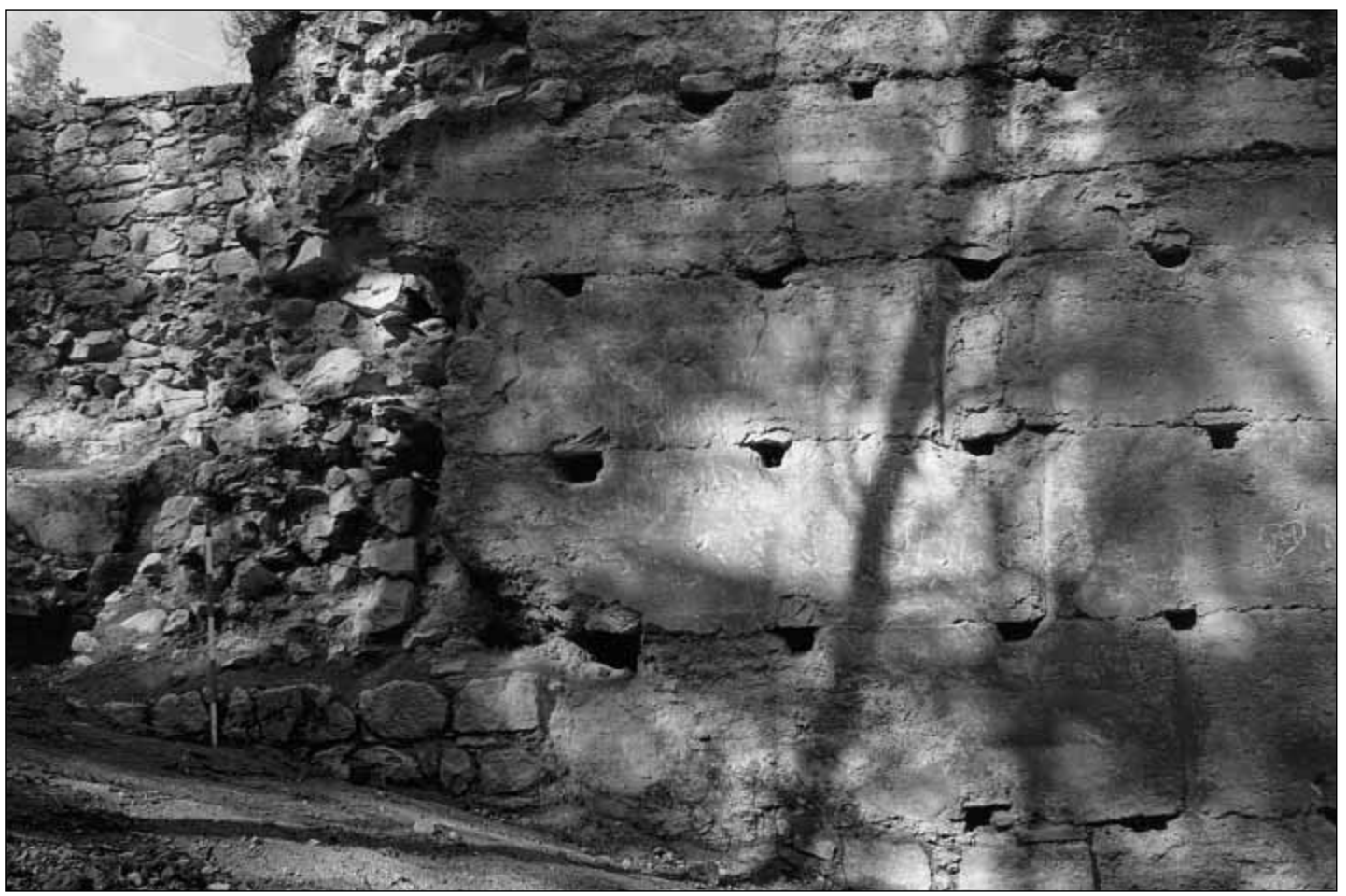



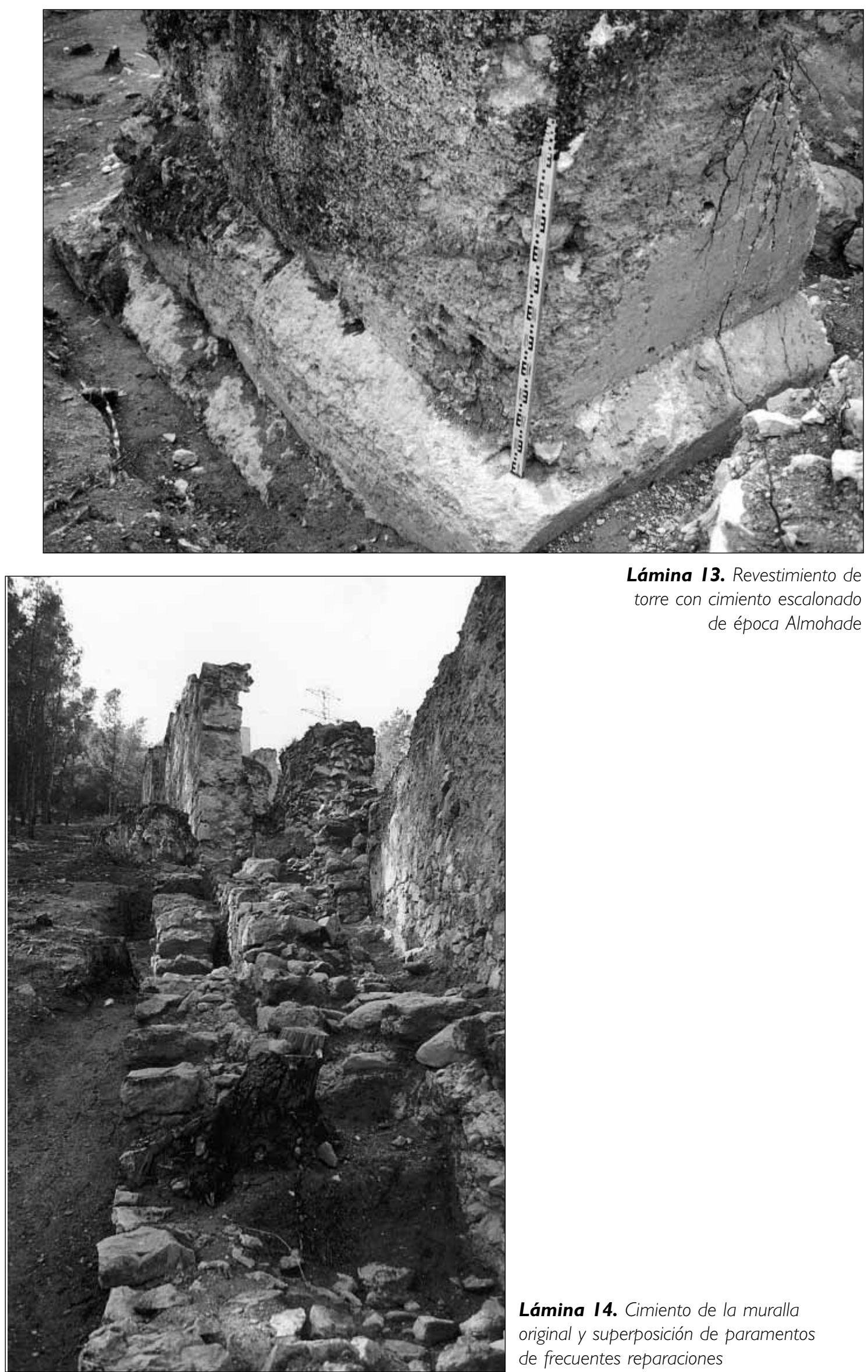

Lámina I3. Revestimiento de torre con cimiento escalonado de época Almohade

Lámina 14. Cimiento de la muralla original y superposición de paramentos de frecuentes reparaciones 


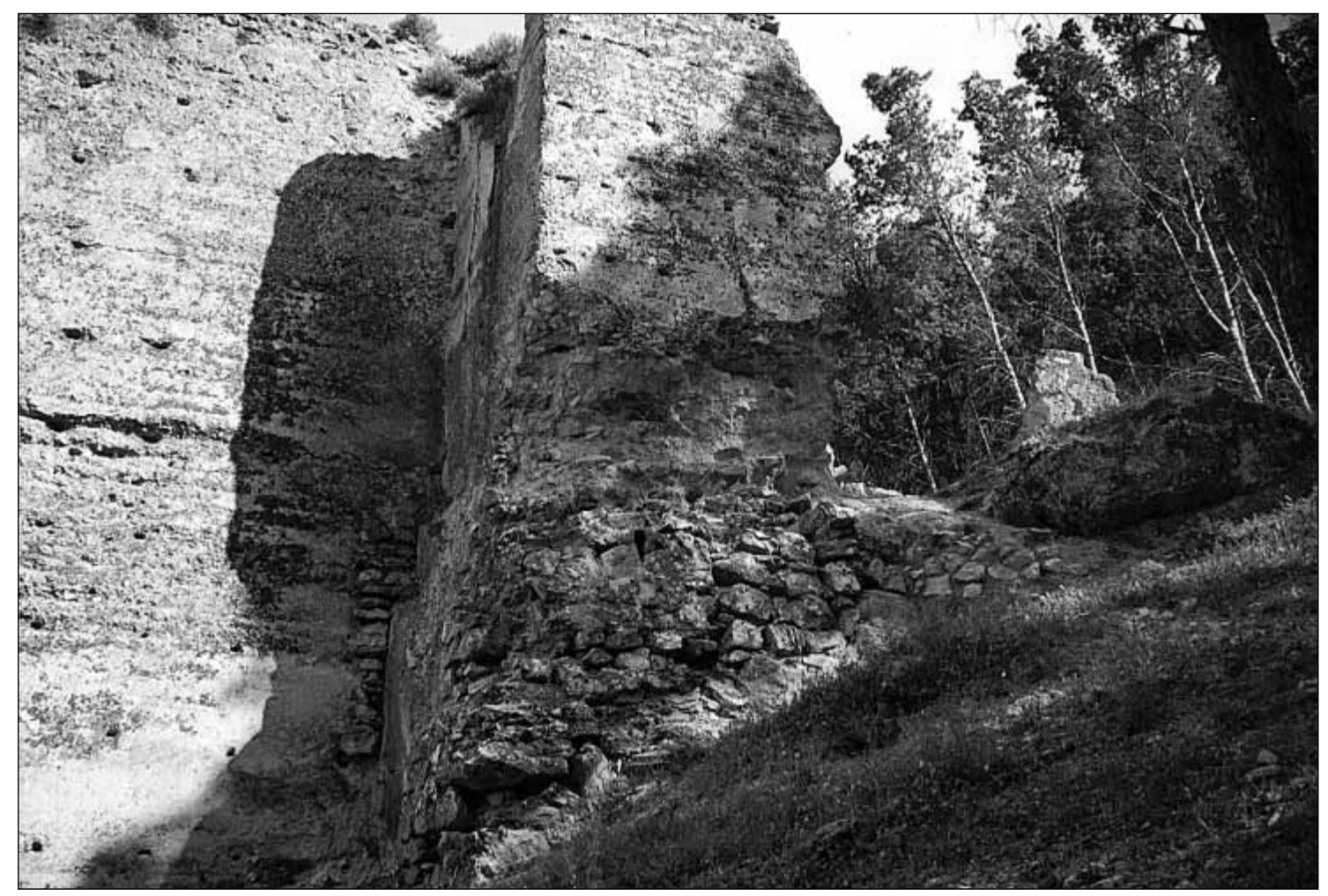

Lámina I5. Torre de origen iberorromano reutilizada durante la Edad Media



Lámina I6. Estado original de las reformas almohades (parte derecha de la fotografía) 


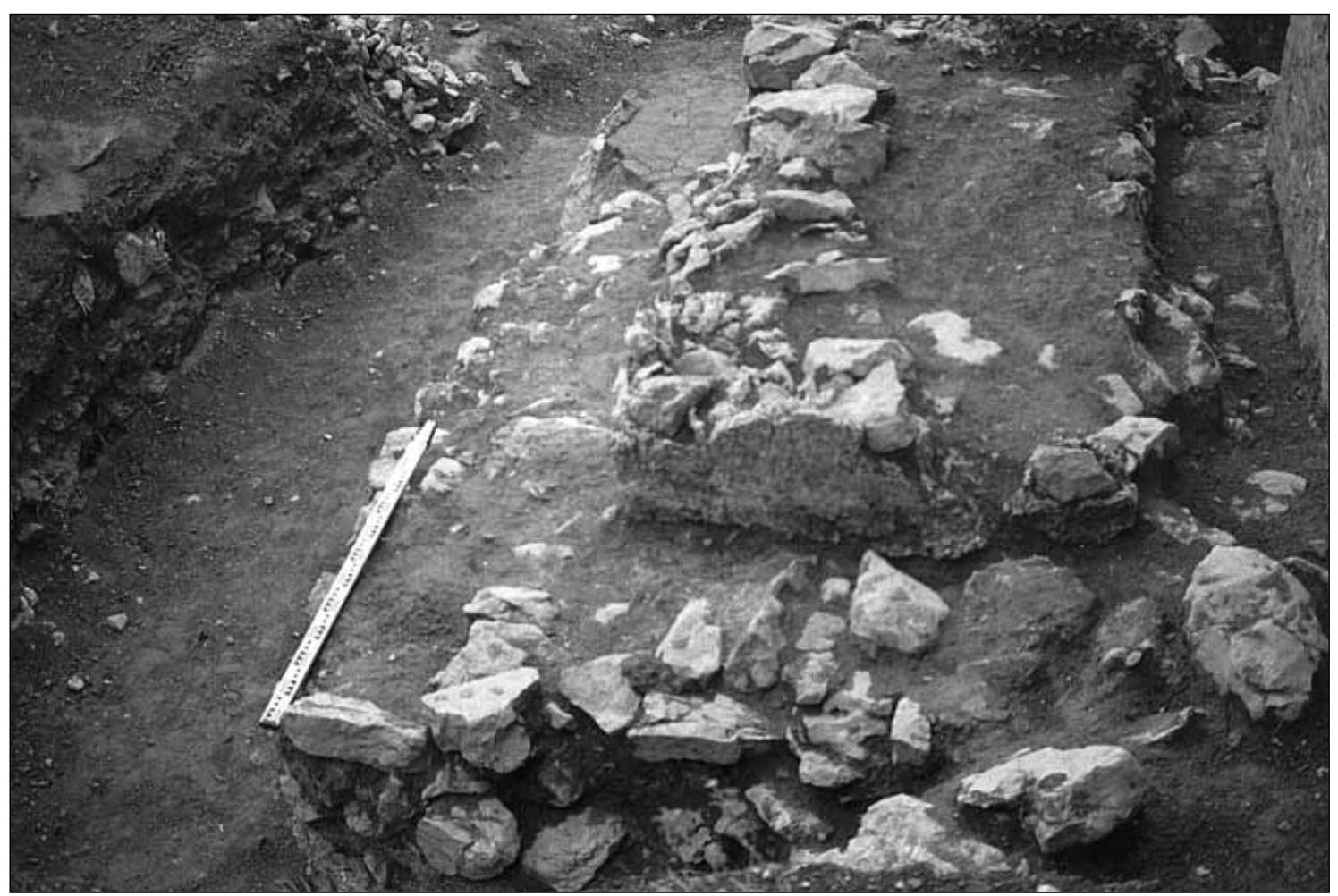

Lámina I7A. Detalla del revestimiento escalonado del cimiento de la torre

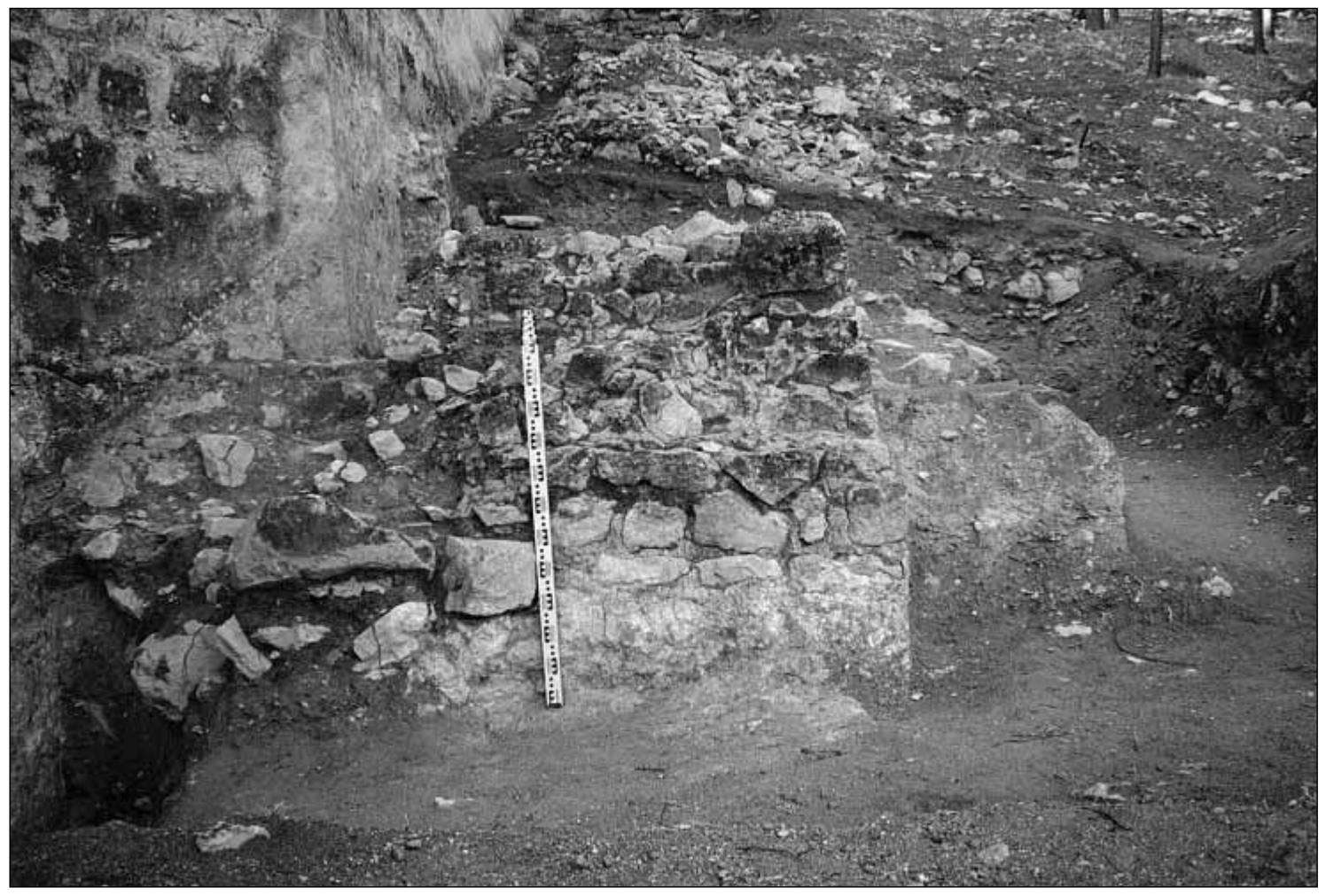

Lámina I7B. Reforma de época cristiana 


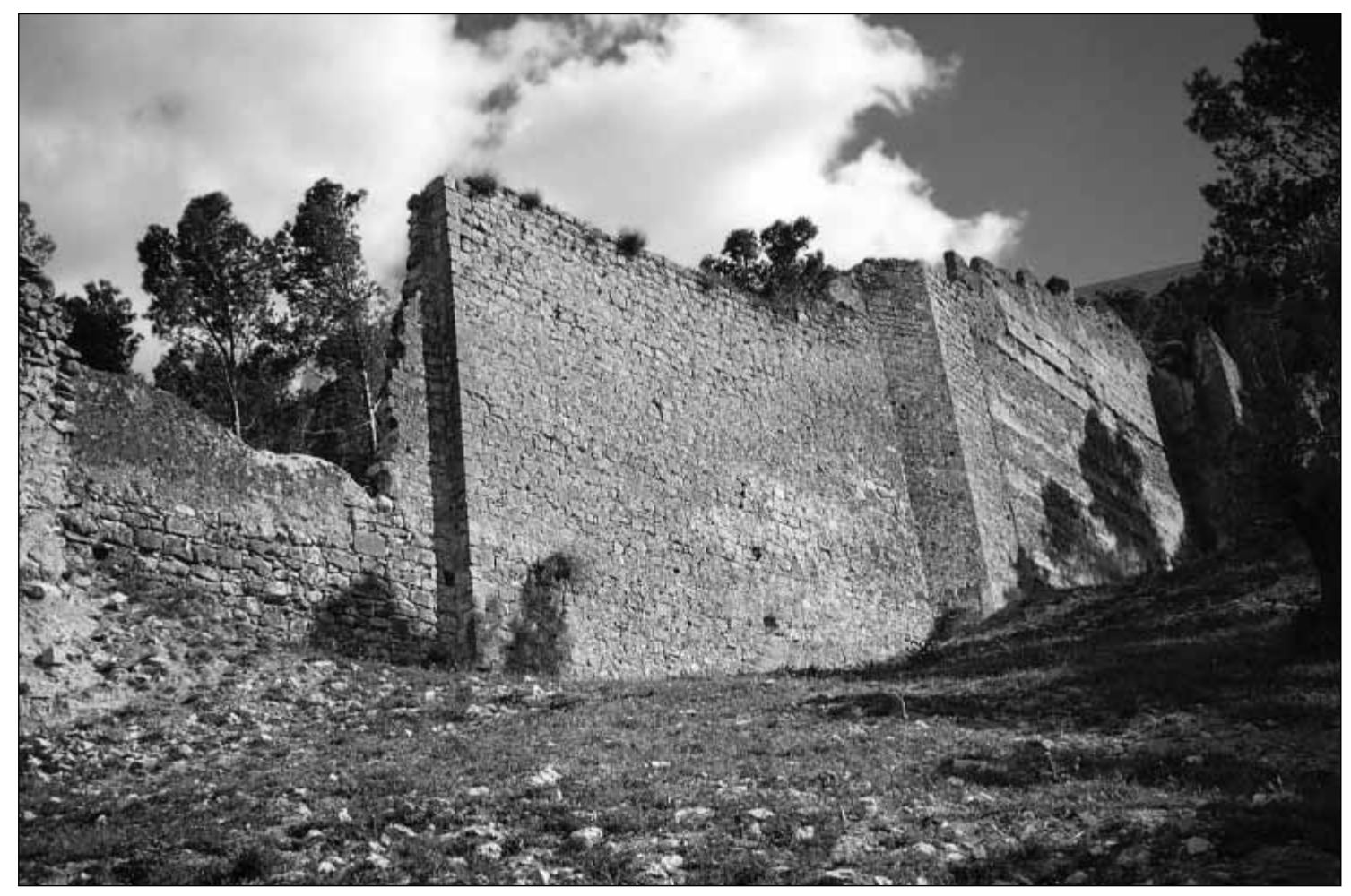

Lámina 18. Estado de conservación de las reformas cristianas

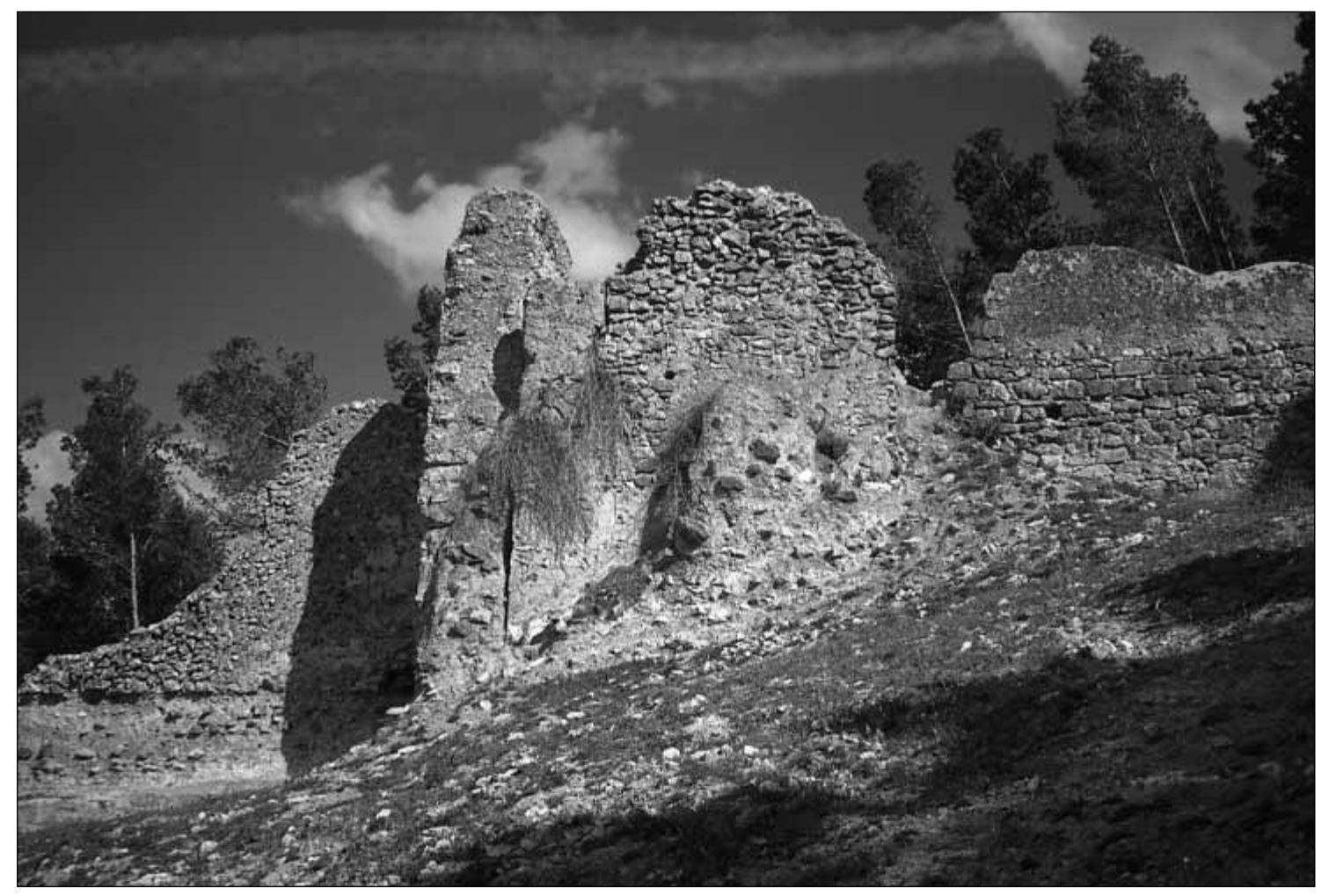

Lámina 19. Detalle de los diferentes "forros" o revestimientos 


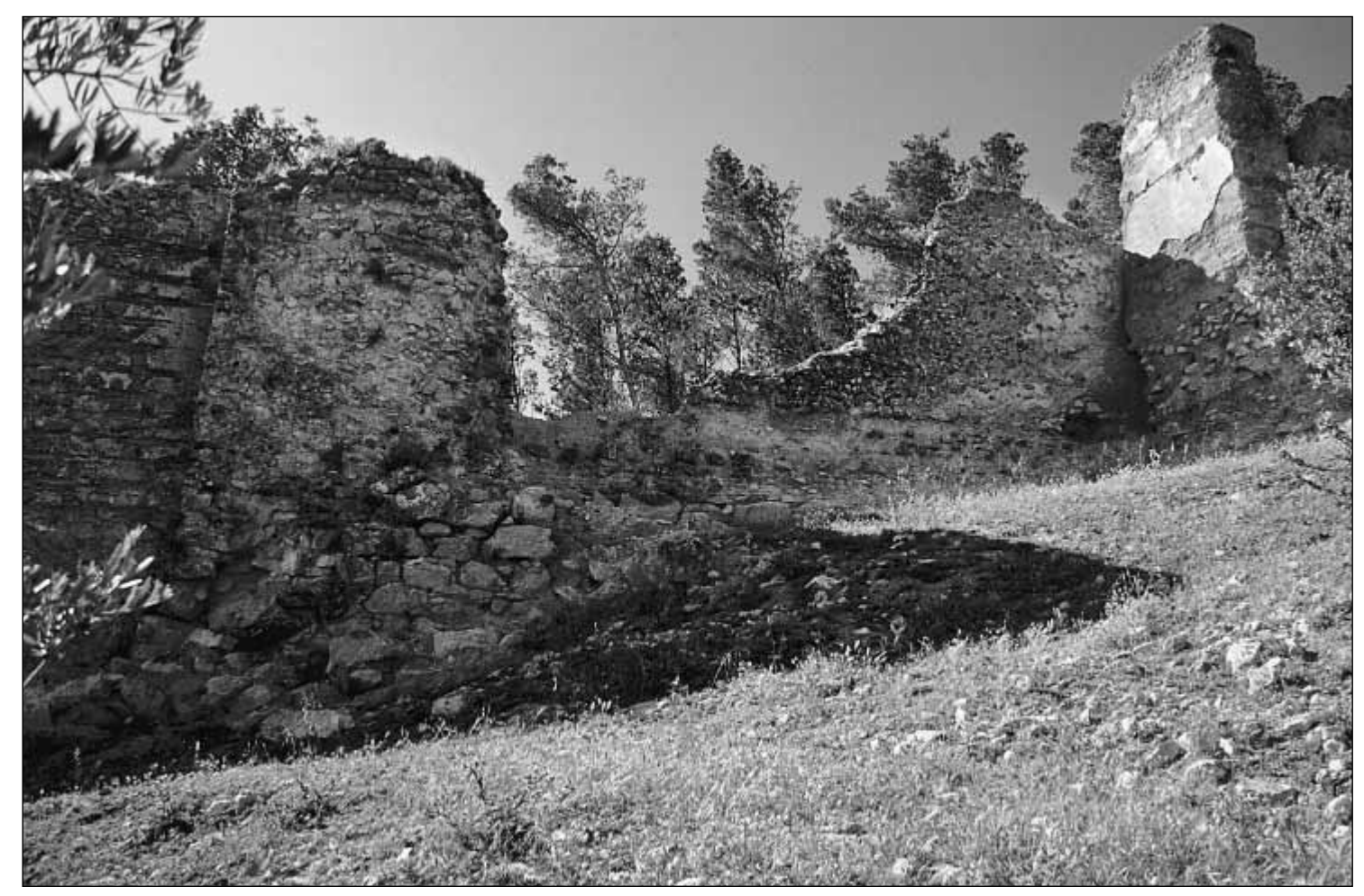

Lámina 20. Reparación con mampostería enlucida con mortero de cal y yeso

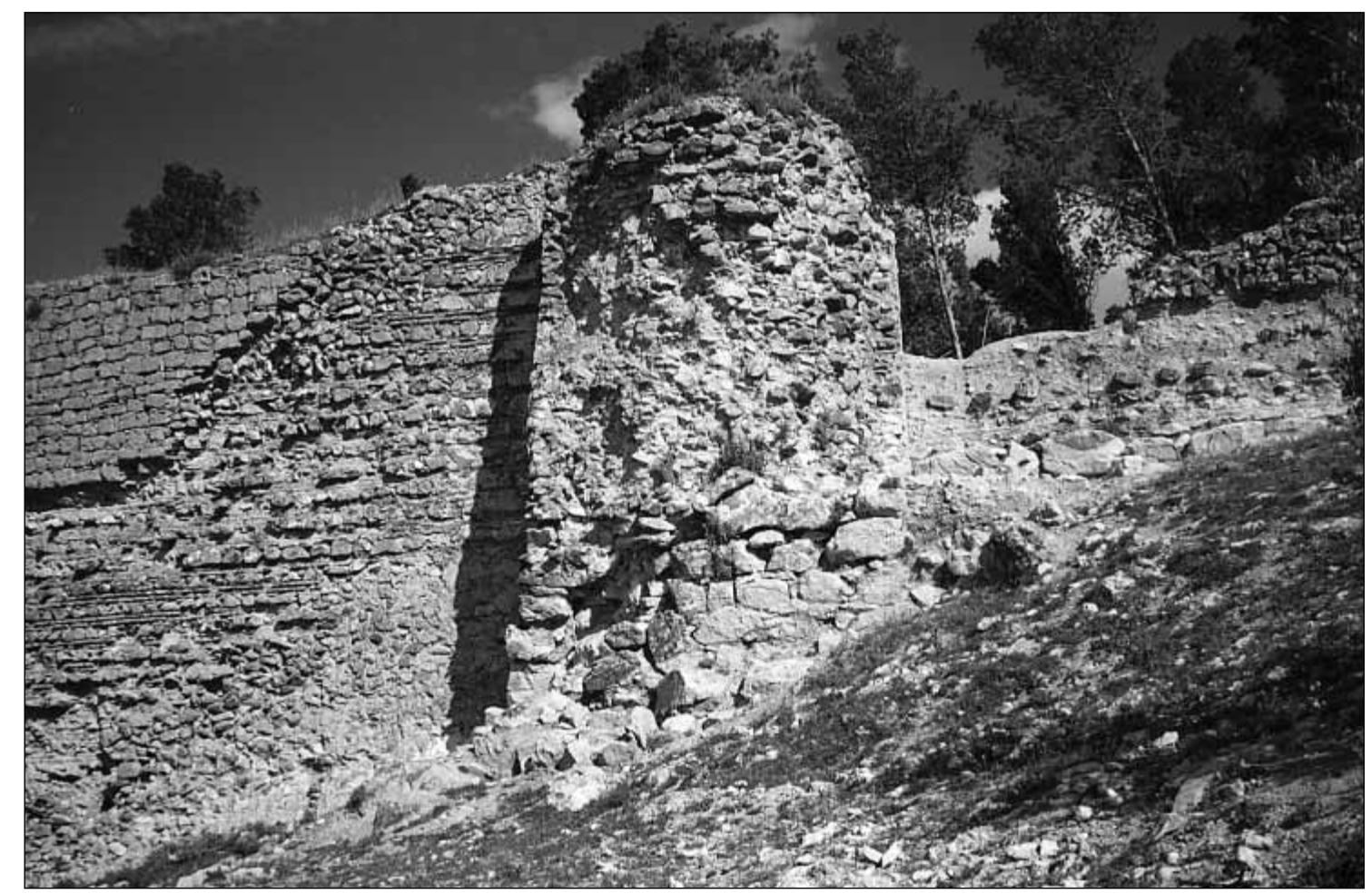

Lámina 2 I. Torre de origen iberorromano con cimiento ciclópeo 


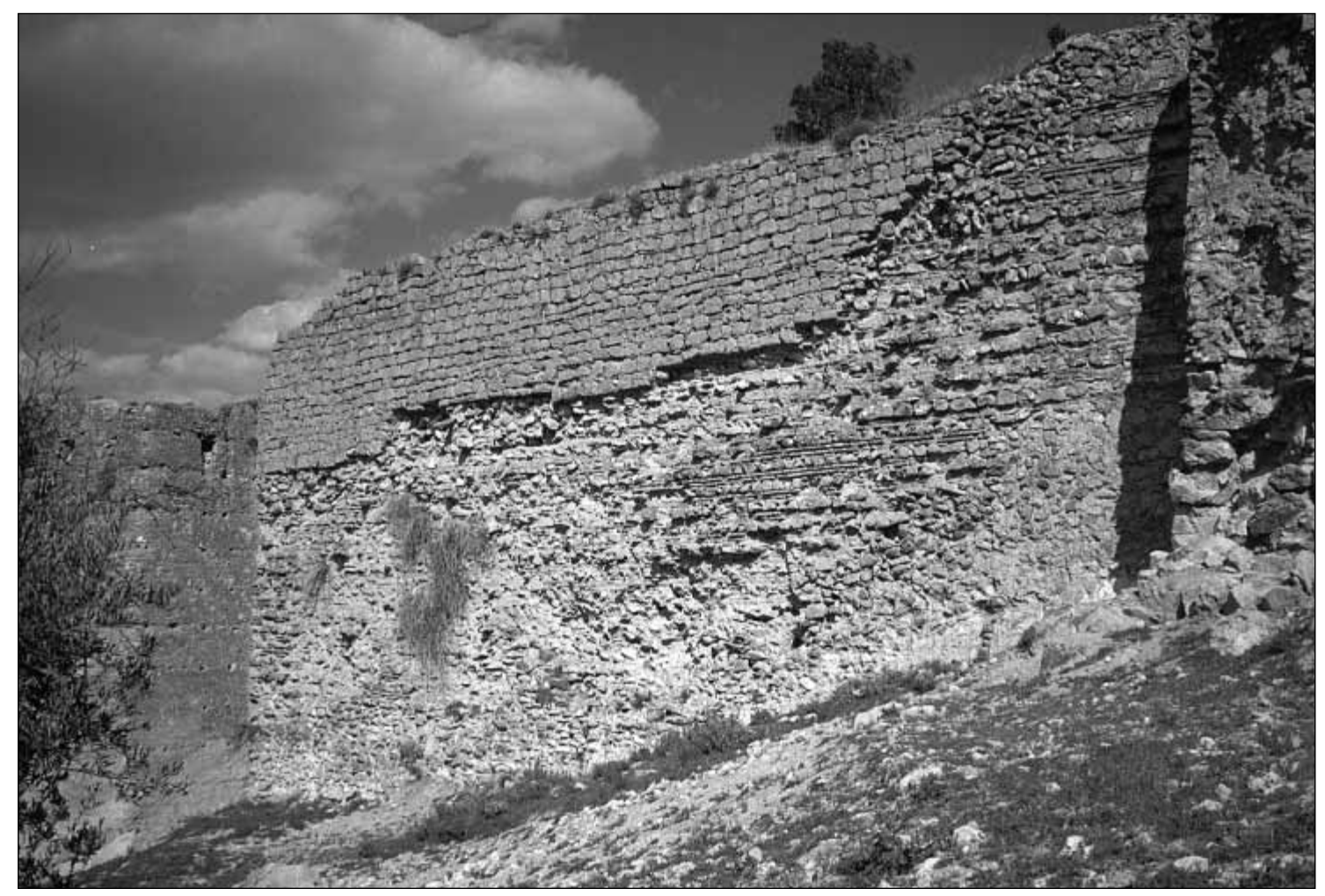

Lámina 22. Superposición de las reformas cristianas

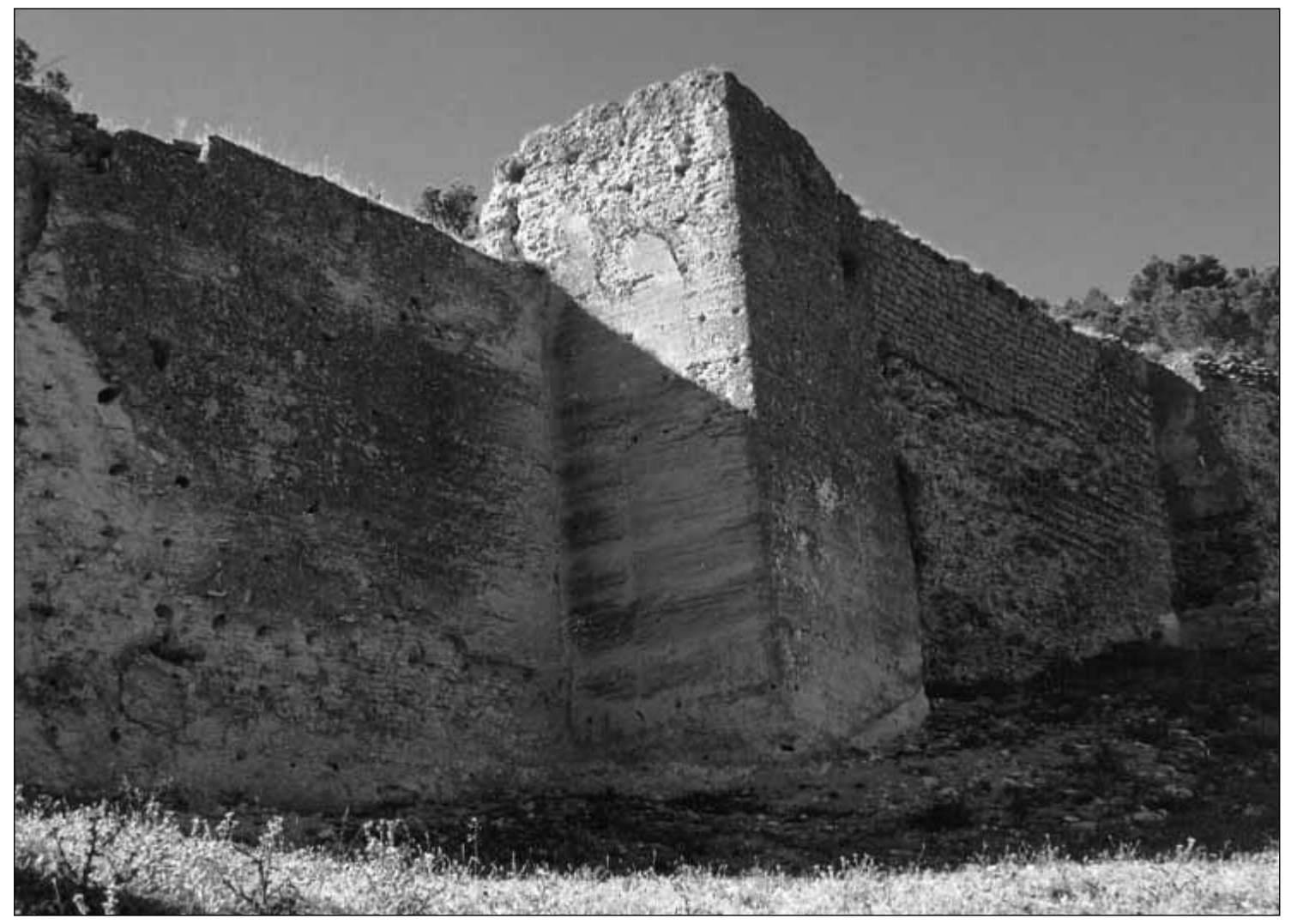

Lámina 23. Torre posiblemente de origen califal 


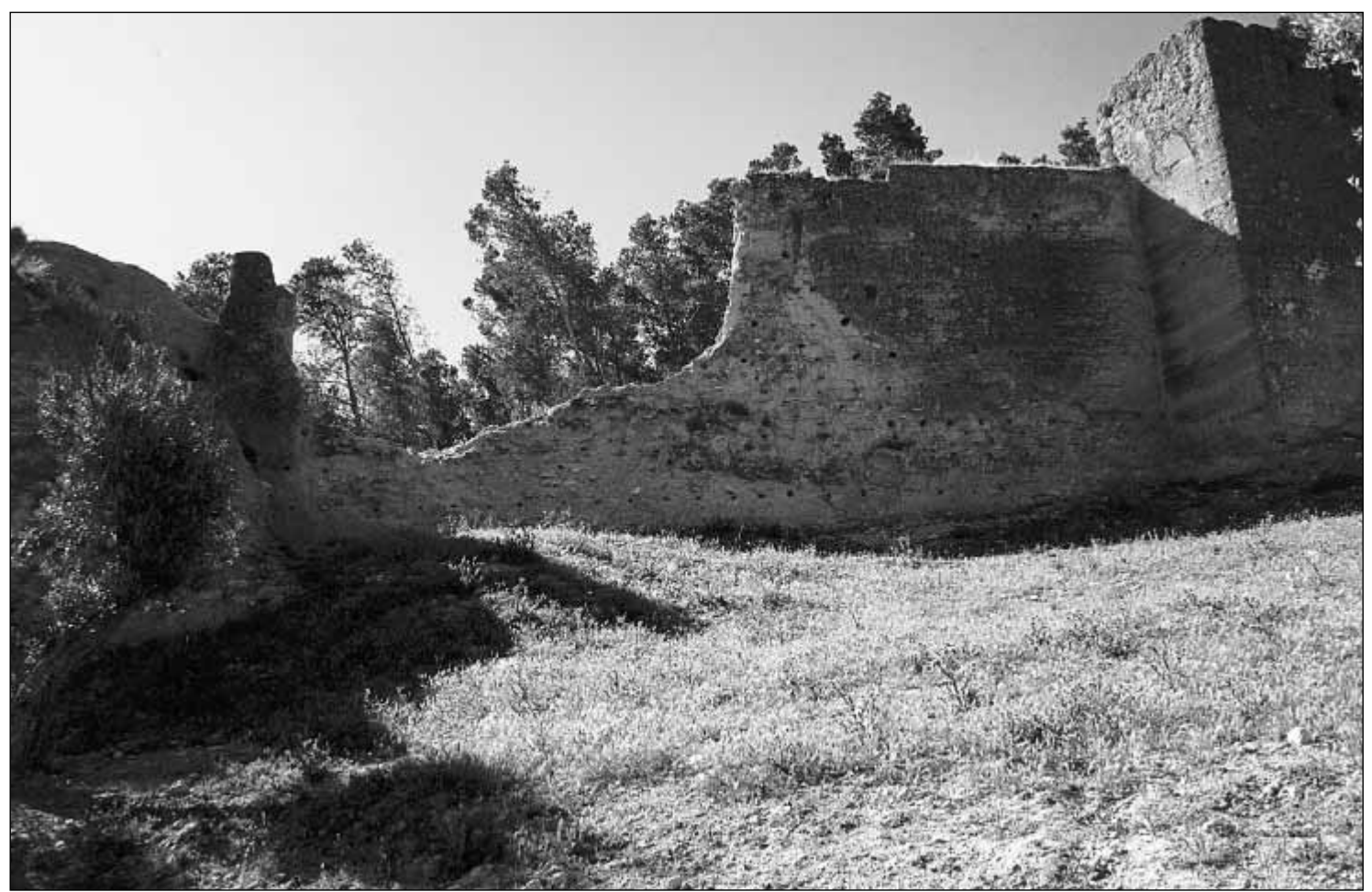

Lámina 24. Revestimiento donde se observa la huella de las "tablillas" del encofrado



Lámina 25A. Torre que protege el portillo de "Puerta Nueva" 


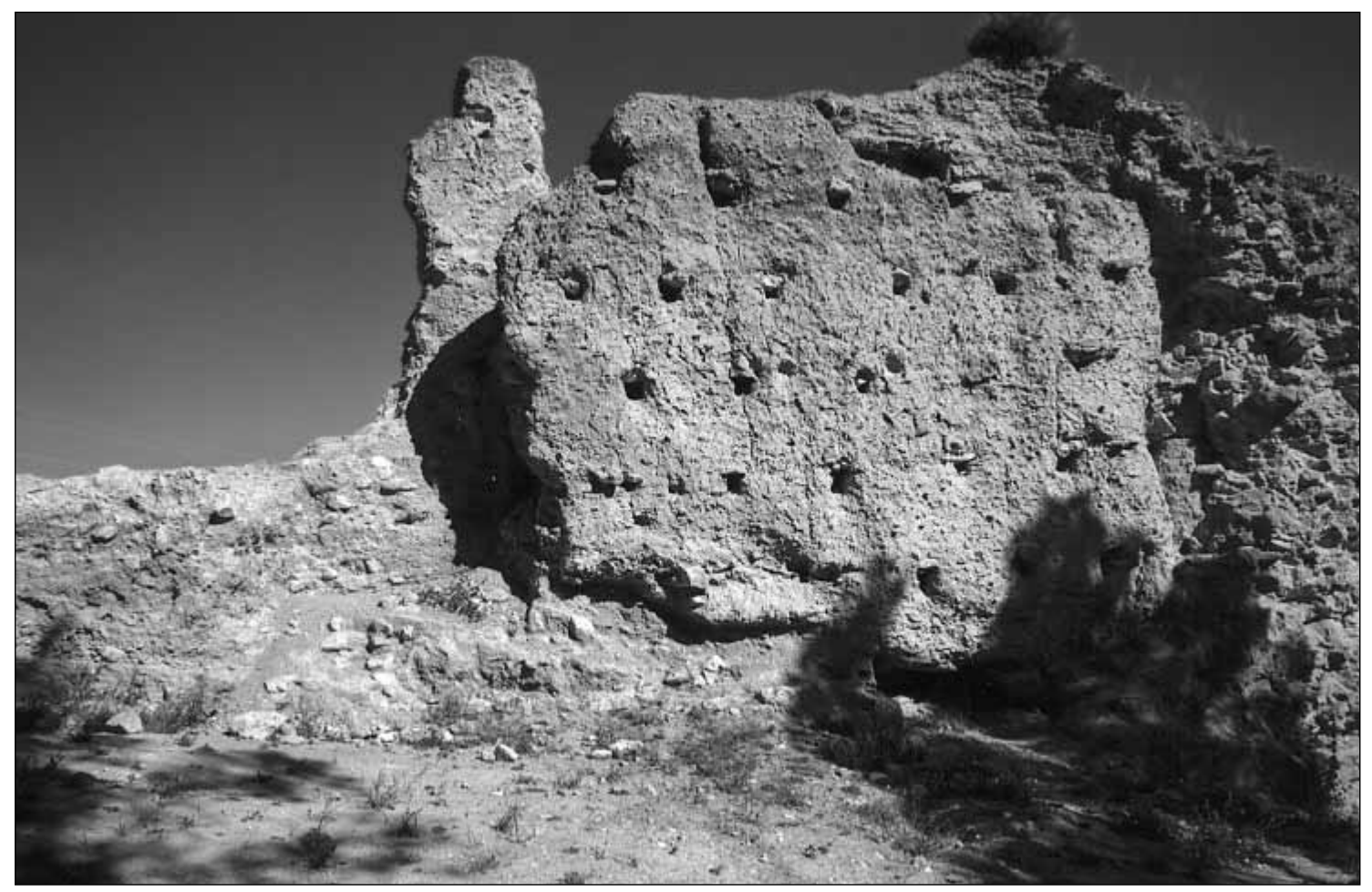

Lámina 25B. Estado de conservación del paramento original intramuros de la torre, donde se aprecian los mechinales

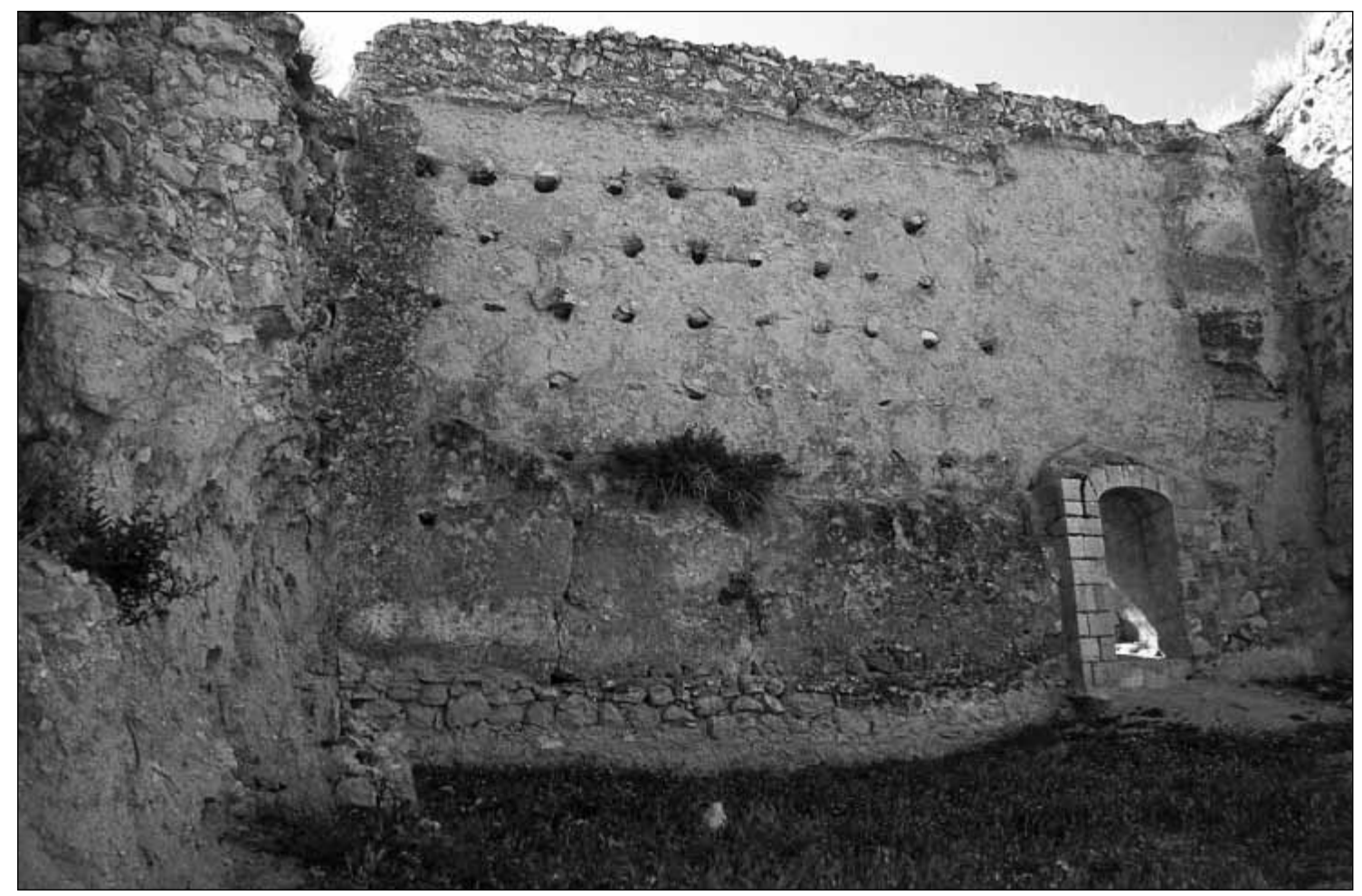

Lámina 26. Lienzo donde se localiza la "Puerta Nueva", hoy día restaurado 


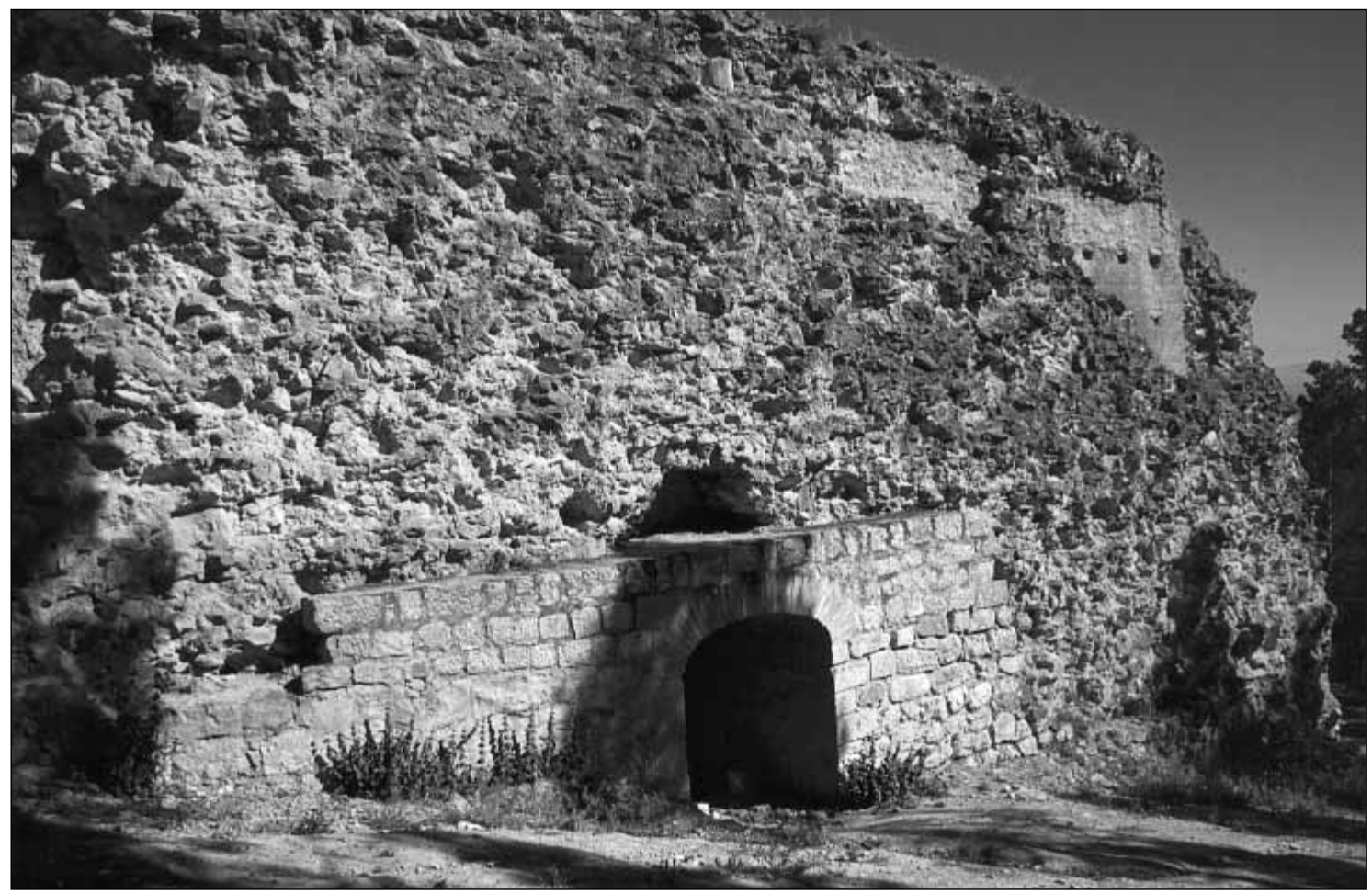

Lámina 27. Reciente restauración del portillo, visto desde intramuros

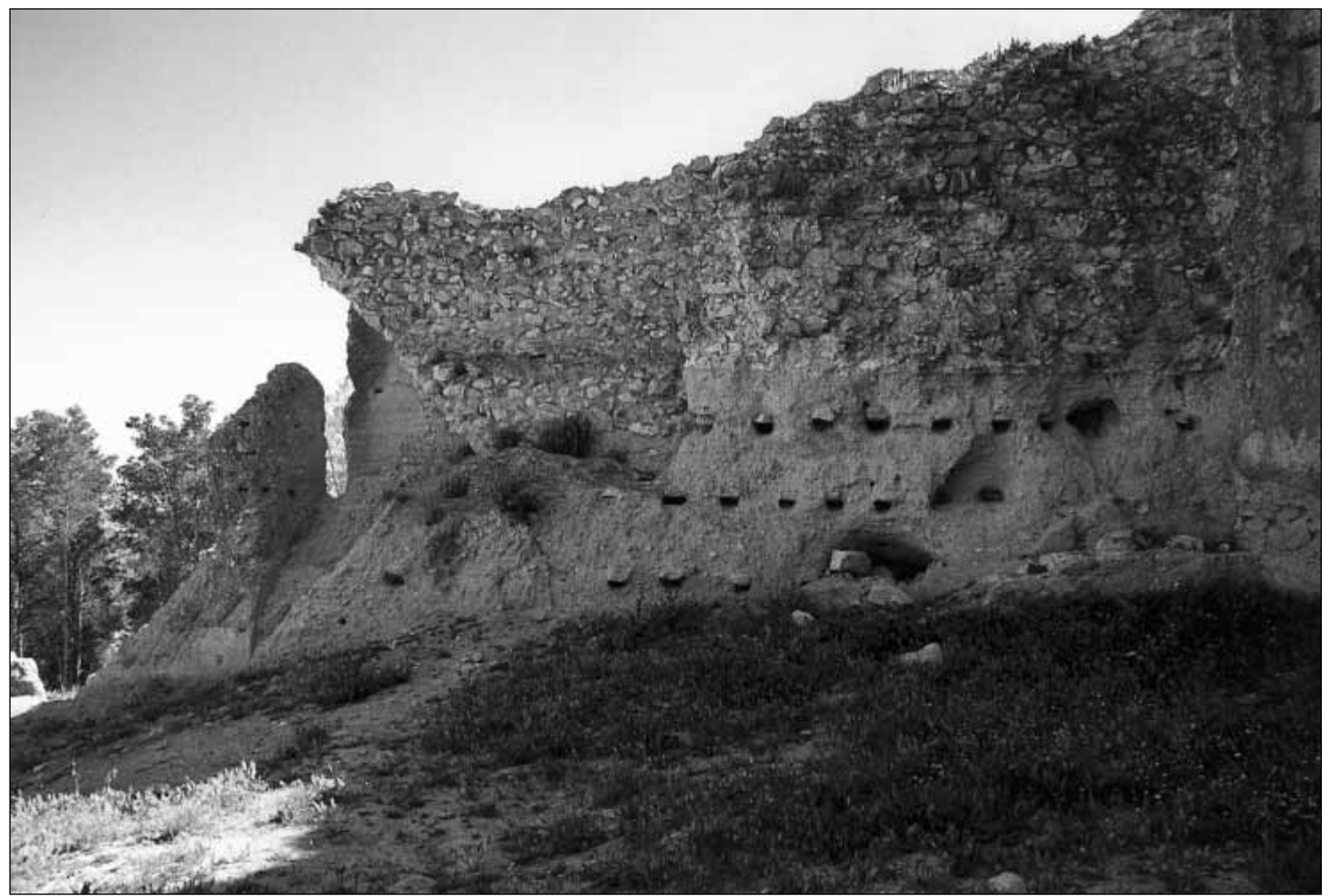

Lámina 28. Tramo de muralla de gran complejidad arquitectónica 


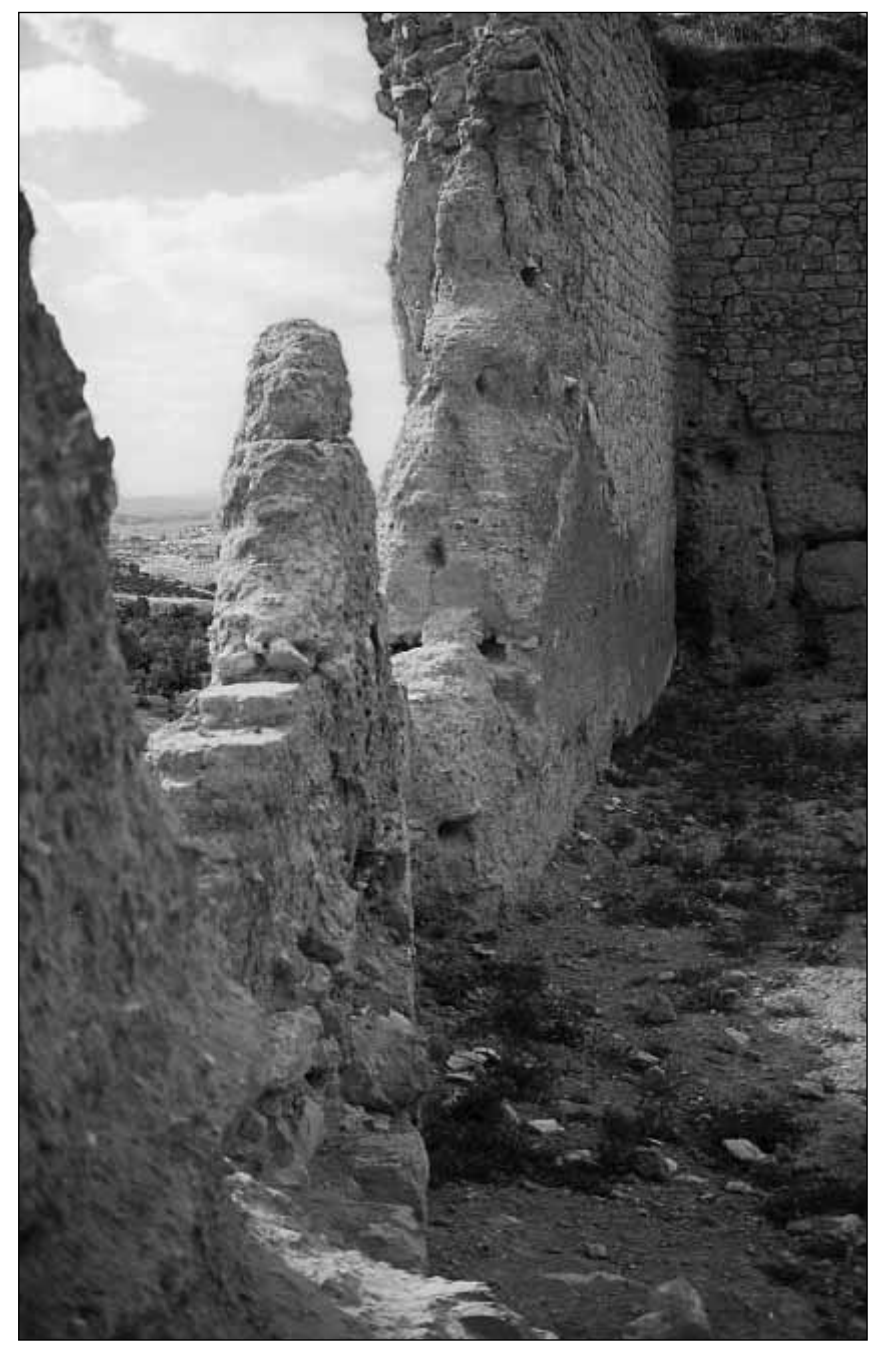

Lámina 29. Quiebro de la muralla

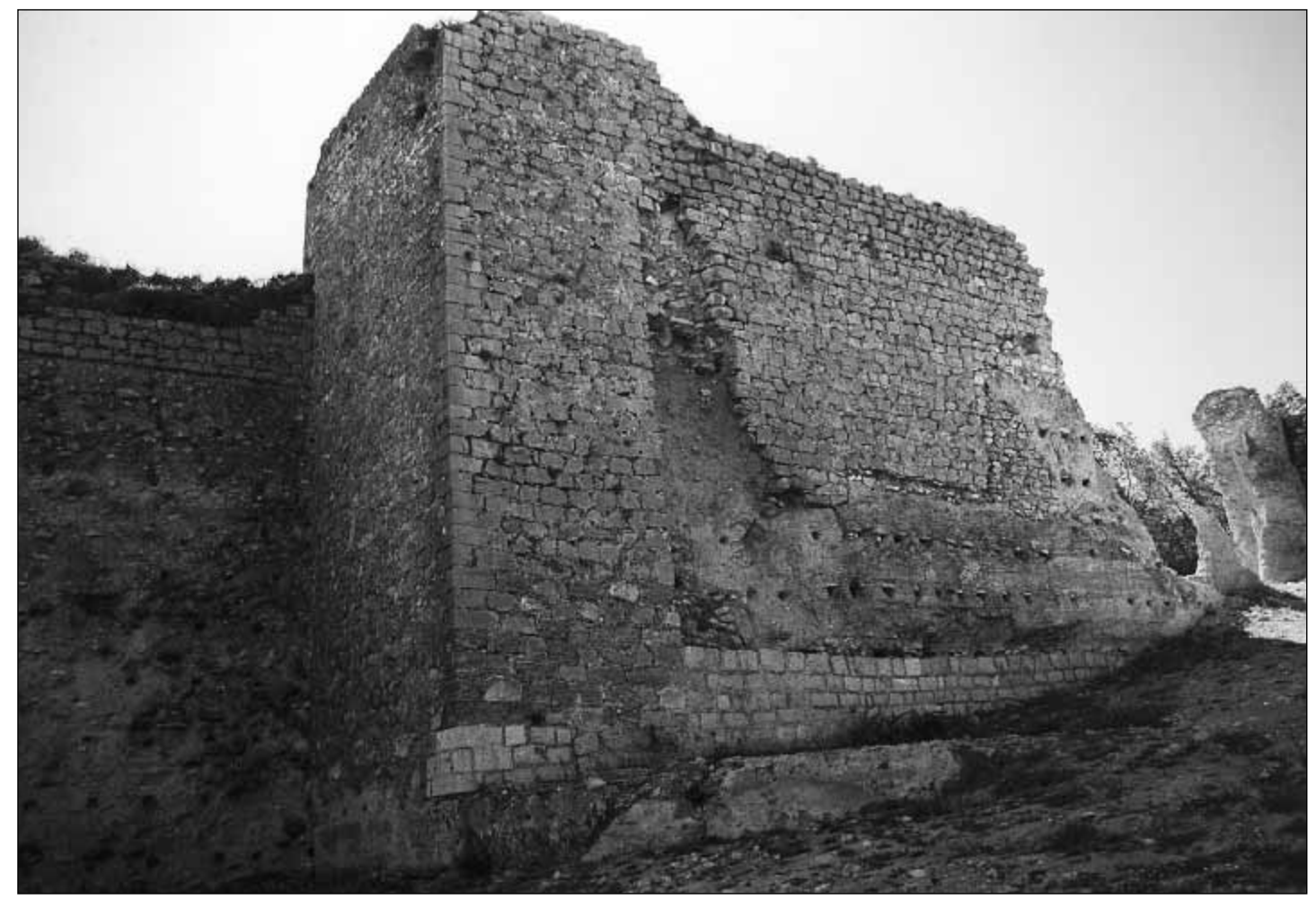




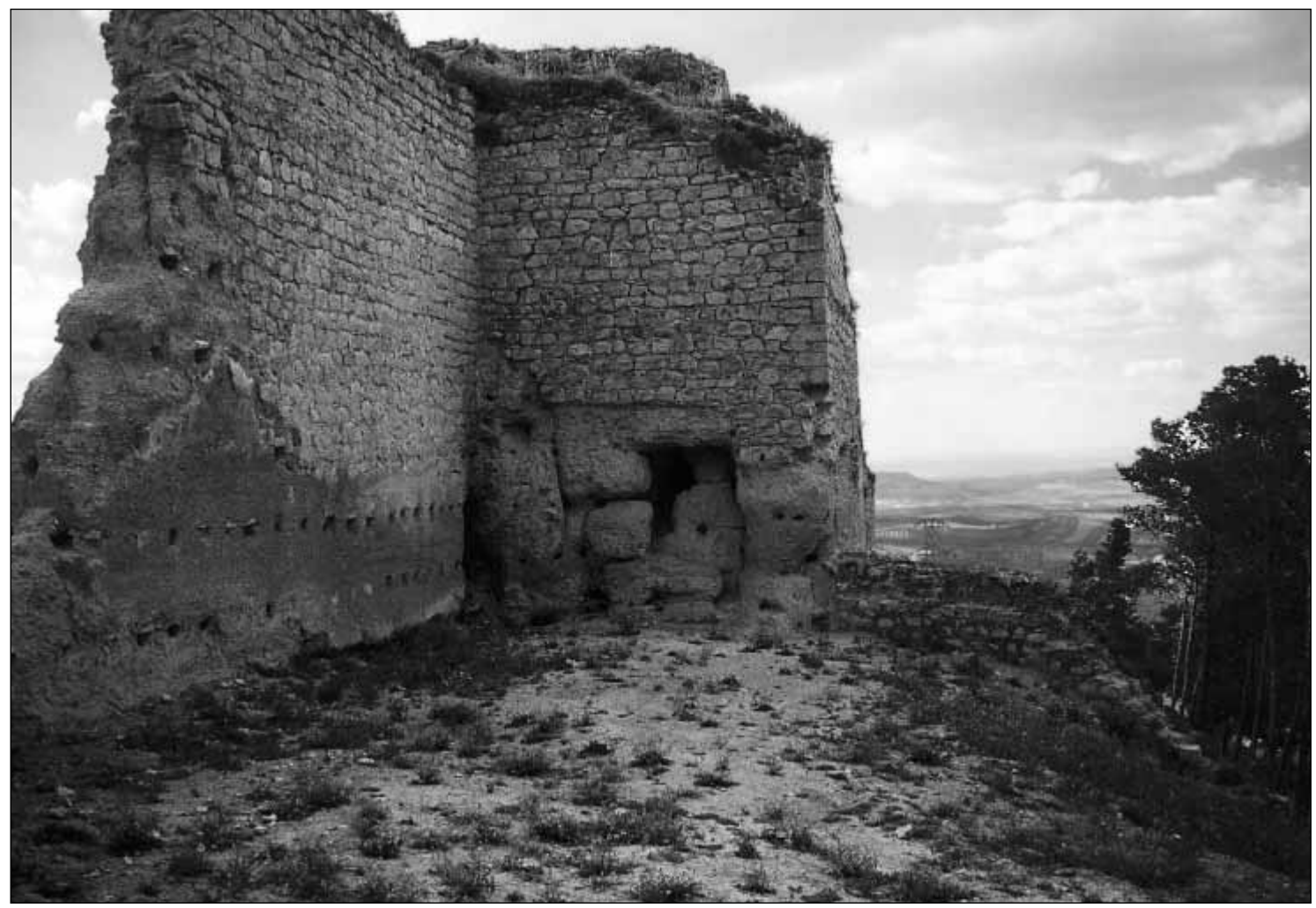

Lámina 30B. Aspecto intramuros de la torre, muy reparada con mampostería

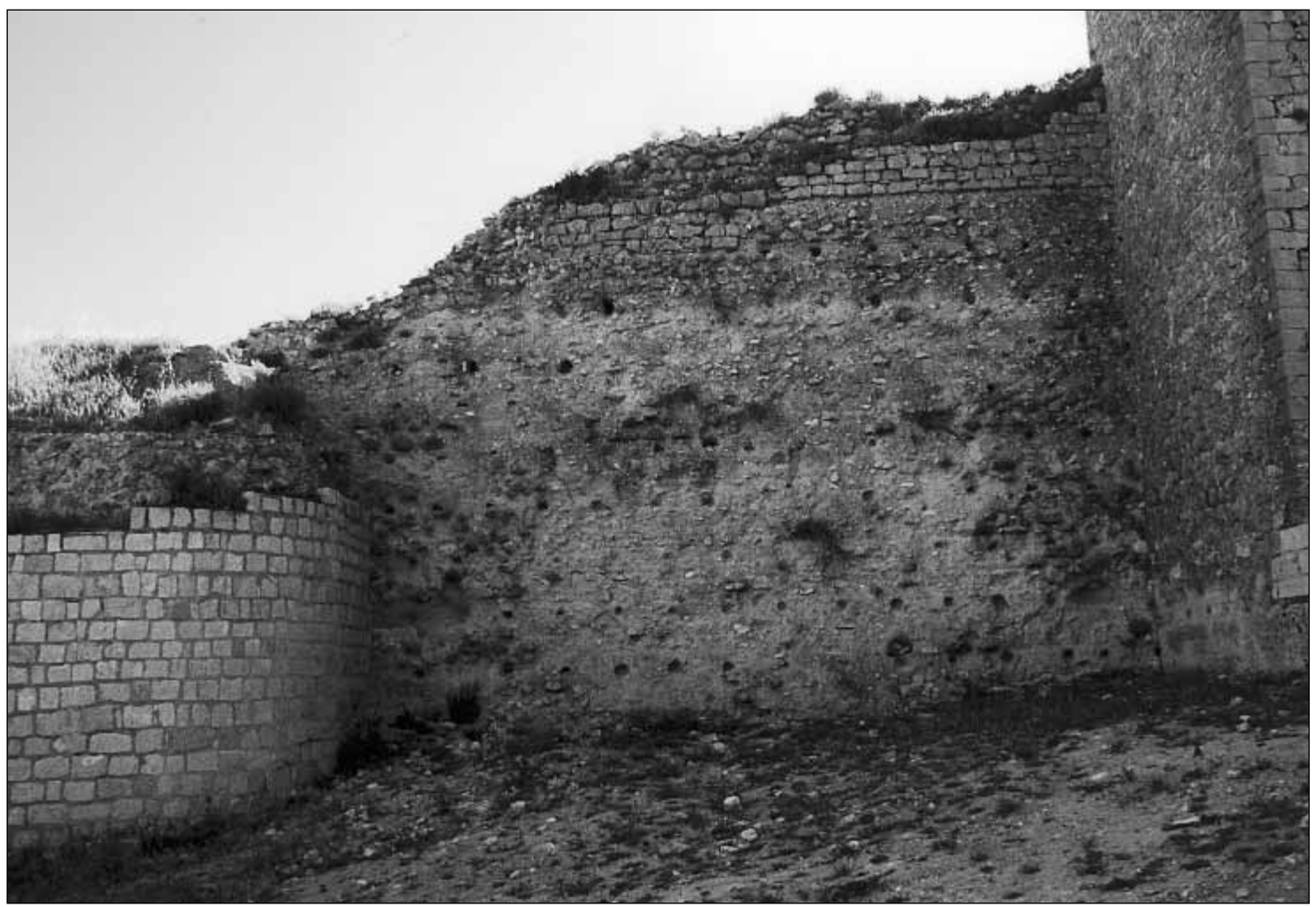

Lámina 3I. Lienzo de tapial, cuyo adarve ha sido recrecido y fortalecido con mampostería 

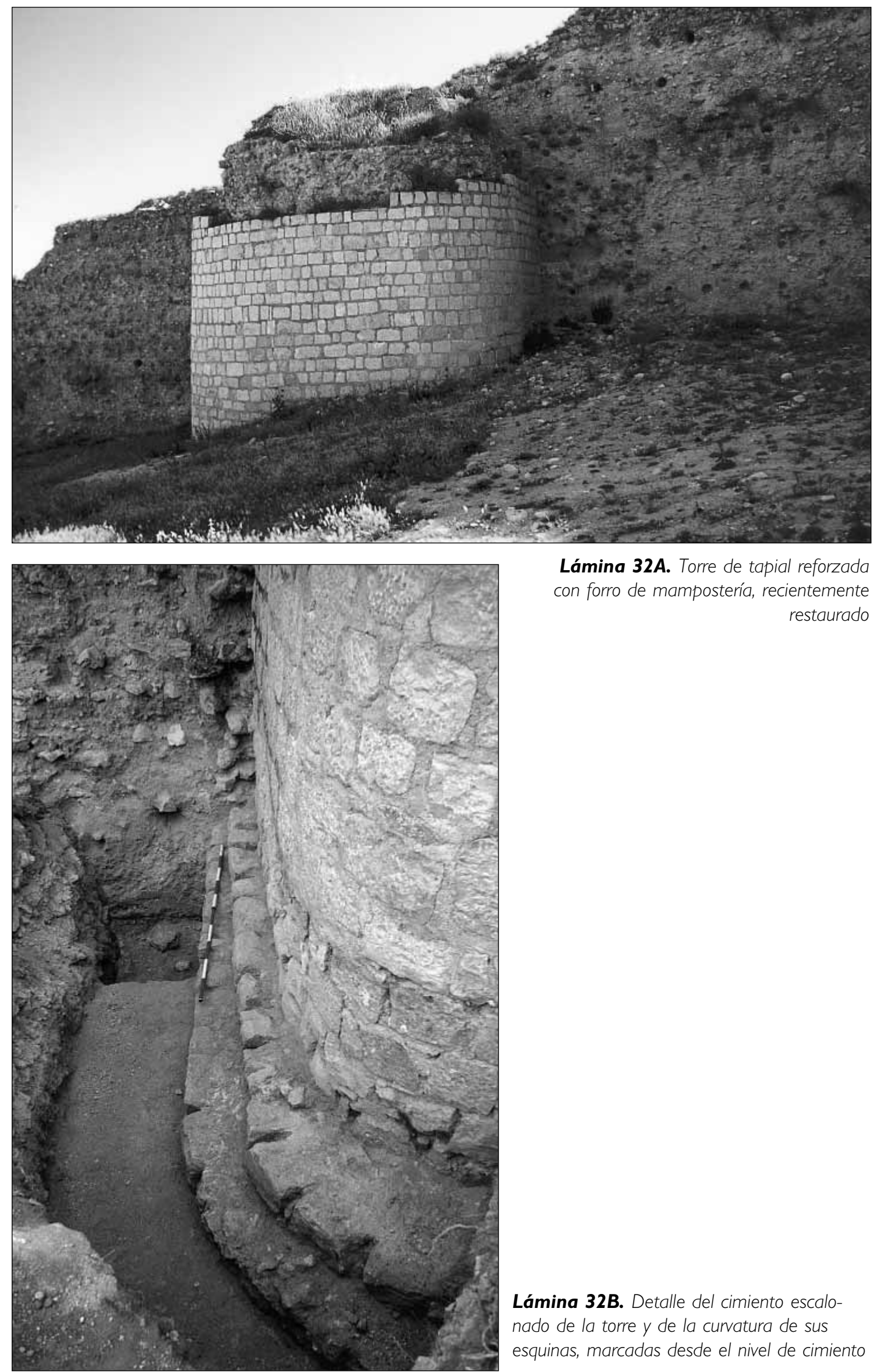

Lámina 32A. Torre de tapial reforzada con forro de mampostería, recientemente restaurado

Lámina 32B. Detalle del cimiento escalonado de la torre y de la curvatura de sus esquinas, marcadas desde el nivel de cimiento 


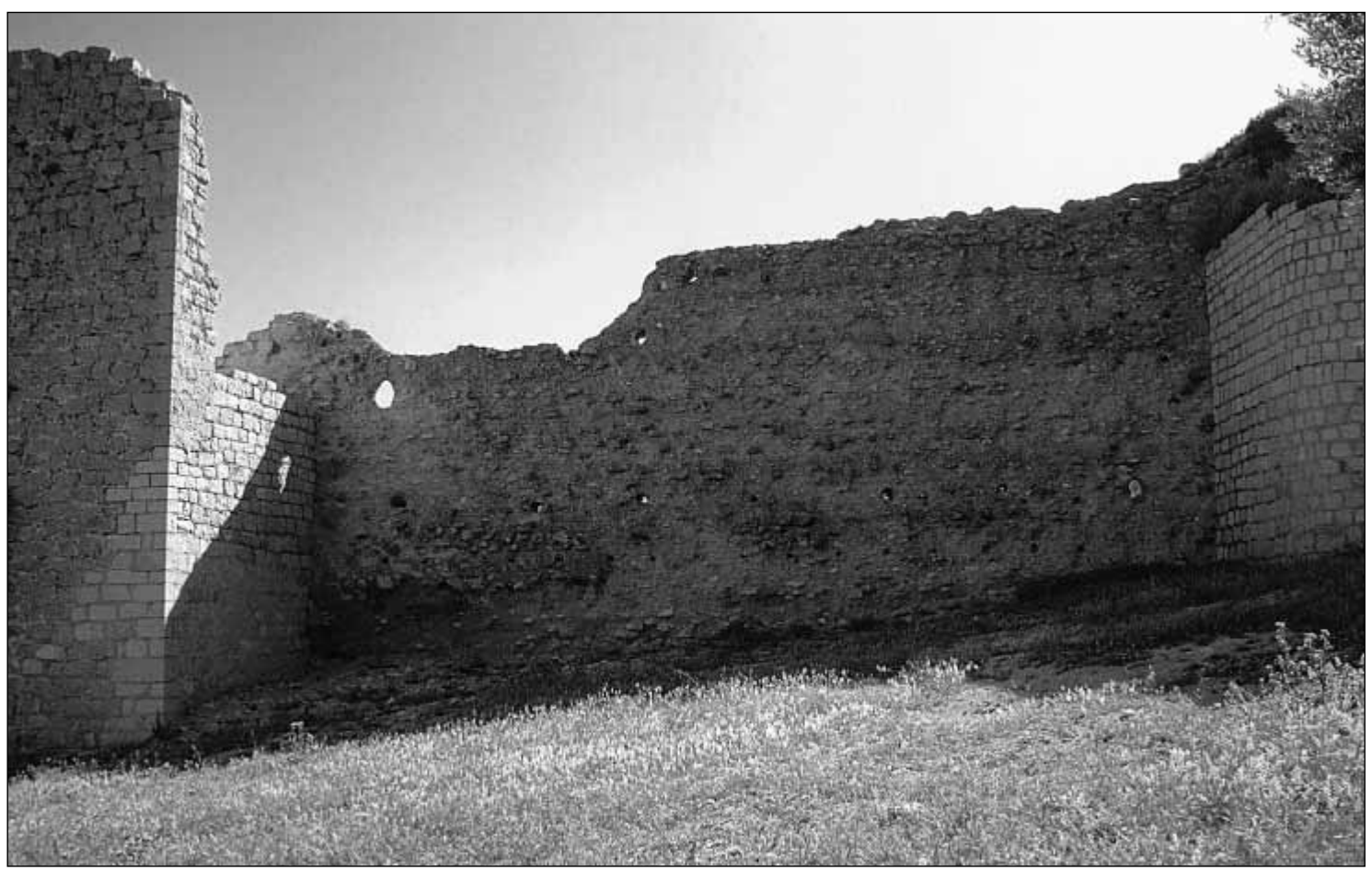

Lámina 33. Revestimiento de tapial de argamasa con numerosos mampuestos

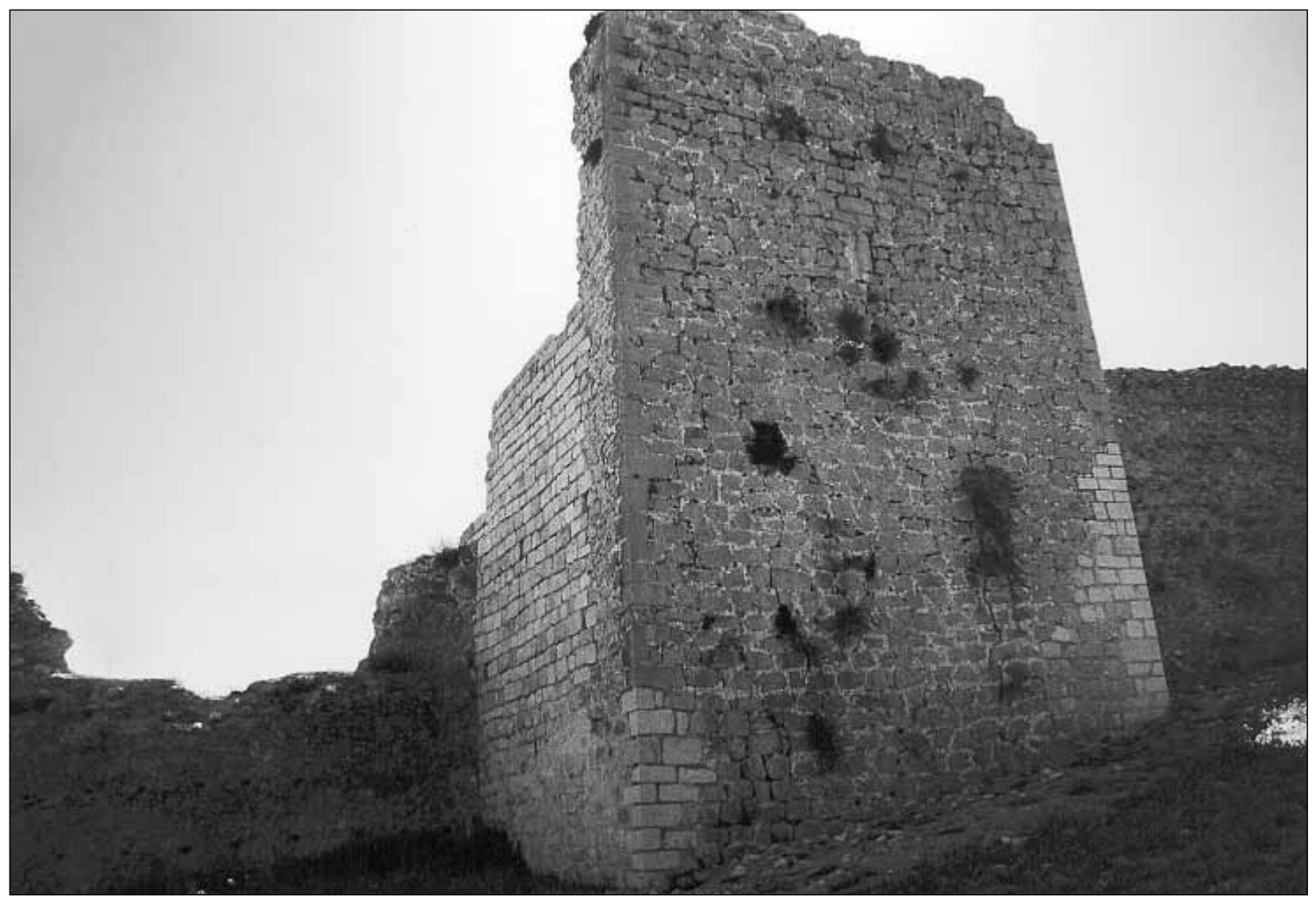

Lámina 34. Torre que conserva restos de la estancia abierta a nivel del adarve, la cual preserva sólo una saetera 




Lámina 35. Unión de revestimientos

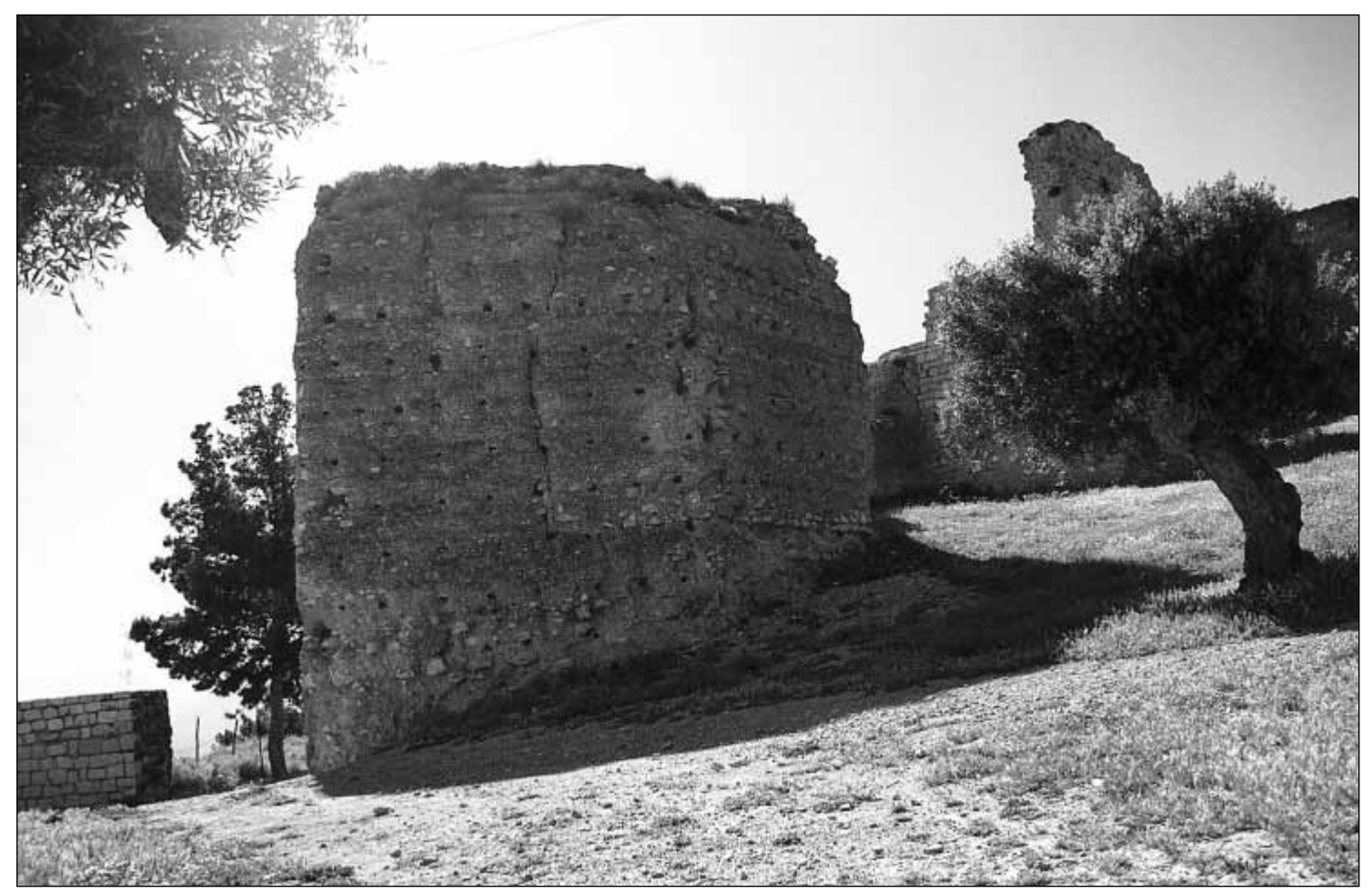

Lámina 36A. Torre pentagonal que protege el "Postigo de la Llana" 
Lámina 36B. Lateral de la torre del que partiría el lienzo en el que se abría el desaparecido "Postigo de la Llana"
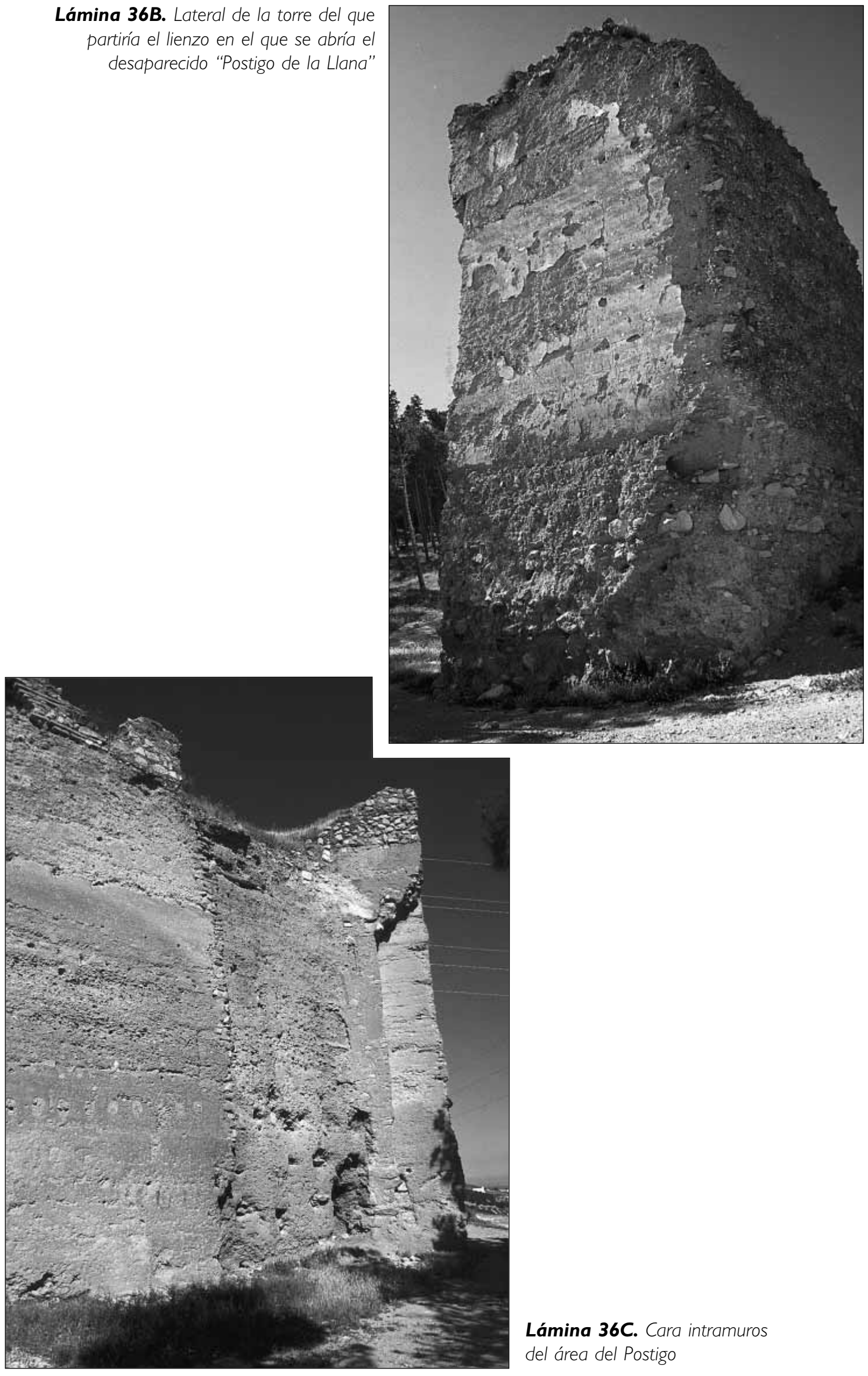

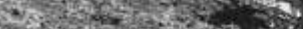




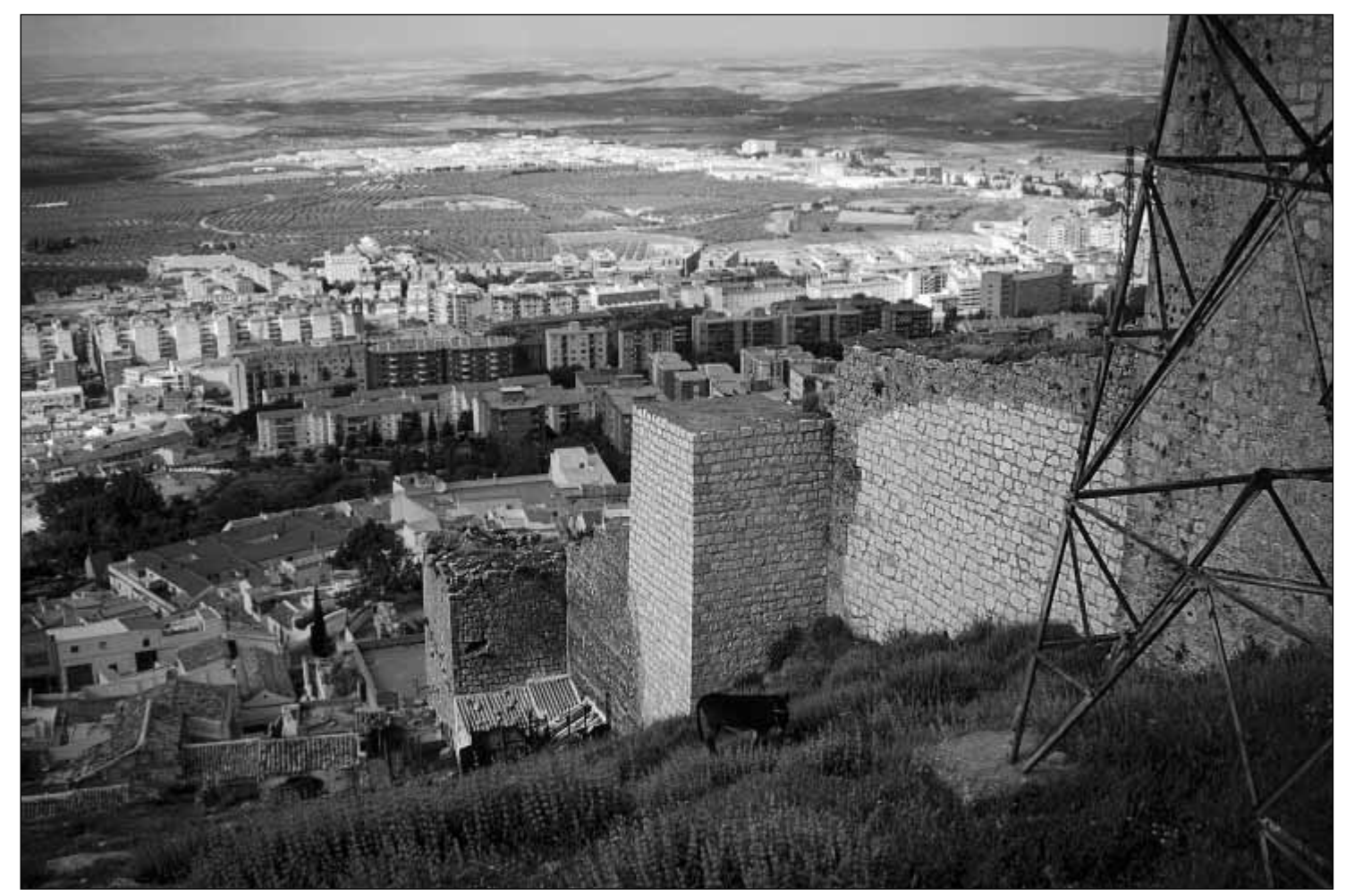

Lámina 37. Tramo de muralla que parte del "Postigo de la Llana" en dirección a la Puerta de Martos 